\title{
Analyzing seasonal patterns of wildfire exposure factors in Sardinia, Italy
}

\author{
Michele Salis • Alan A. Ager • Fermin J. Alcasena • \\ Bachisio Arca • Mark A. Finney • Grazia Pellizzaro • \\ Donatella Spano
}

Received: 24 July 2014 / Accepted: 17 November 2014 / Published online: 4 December 2014

(C) The Author(s) 2014. This article is published with open access at Springerlink.com

\begin{abstract}
In this paper, we applied landscape scale wildfire simulation modeling to explore the spatiotemporal patterns of wildfire likelihood and intensity in the island of Sardinia (Italy). We also performed wildfire exposure analysis for selected highly valued resources on the island to identify areas characterized by high risk. We observed substantial variation in burn probability, fire size, and flame length among time periods within the fire season, which starts in early June and ends in late September. Peak burn probability and flame length were observed in late July. We found that patterns of wildfire likelihood and intensity were mainly related to
\end{abstract}

M. Salis $(\bowtie) \cdot$ D. Spano

Department of Science for Nature and Environmental

Resources (DIPNET), University of Sassari,

Via De Nicola 9, 07100 Sassari, Italy

e-mail: miksalis@uniss.it

M. Salis · F. J. Alcasena • D. Spano

Euro-Mediterranean Center on Climate Change (CMCC), IAFENT Division,

Via De Nicola 9, 07100 Sassari, Italy

A. A. Ager

USDA Forest Service, Pacific Northwest Research Station, Western Wildland Environmental Threat Assessment Center, 3160 NE 3rd Street, Prineville, OR 97754, USA

B. Arca $\cdot$ G. Pellizzaro

National Research Council (CNR), Institute of

Biometeorology (IBIMET),

Traversa La Crucca 3, 07100 Sassari, Italy

M. A. Finney

Rocky Mountain Research Station, Fire Sciences Laboratory,

5775 Highway 10 West, Missoula, MT 59808, USA spatiotemporal variation in ignition locations, fuel moisture, and wind vectors. Our modeling approach allowed consideration of historical patterns of winds, ignition locations, and live and dead fuel moisture on fire exposure factors. The methodology proposed can be useful for analyzing potential wildfire risk and effects at landscape scale, evaluating historical changes and future trends in wildfire exposure, as well as for addressing and informing fuel management and risk mitigation issues.

Keywords Burn probability · Fire exposure · Fire risk - Mediterranean areas. MTT algorithm. Seasonal patterns . Fire modeling

\section{Introduction}

Understanding spatiotemporal patterns in wildfire exposure and risk and the underlying drivers remains a key challenge for fire scientists and land managers, especially in the case of large catastrophic fires that cause most of the human, financial, and ecological losses (Pereira et al. 2005; Ager et al. 2012; Parisien et al. 2012; Ganteaume and Jappiot 2013). While fuel moisture and load, extreme weather, and topography all contribute to wildfire risk (Pyne et al. 1996; Moreira et al. 2011), human behavior as it relates to the timing and location of ignitions is also a key factor (Martinez et al. 2009; Skinner et al. 2009; González-Olabarria et al. 2012; Lovreglio et al. 2012; San Miguel-Ayanz et al. 2013). The allocation of fire suppression resources 
during peak periods of fire occurrence is another major determinant in terms of ignitions escaping initial attack and becoming large fires (Hirsch and Martell 1996; Arienti et al. 2006; Plucinski et al. 2012; Plucinski 2013). In the Mediterranean region, which has seen a dramatic increase in wildfire activity in the 1990s (Moreno et al. 1998; Pausas 2004; Viegas et al. 2009), variation among fire seasons has been specifically linked to fuel moisture and load and to weather conditions (Mouillot et al. 2003; Pellizzaro et al. 2007; Pausas and Fernandez-Munoz 2012; Curt et al. 2013; Xystrakis et al. 2013). For instance, between early July and the end of August, the Mediterranean basin areas experience periods of strong winds, high temperatures, and low atmospheric relative humidity (Pereira et al. 2005; Cardil et al. 2013, 2014). Under such extreme environmental conditions, spread and intensity of wildfires often overwhelm the suppression capabilities of ground and aerial fire-fighting efforts, resulting in a higher probability of large fires and associated impacts (Arienti et al. 2006; Moreira et al. 2011; Brotons et al. 2013; Cardil and Molina 2013).

Several studies defined and characterized wildfire risk in the Mediterranean Basin using a variety of approaches. Most studies have either investigated the relationship between fire risk, meteorological conditions, and biophysical variables (Verde and Zezere 2010; Moreira et al. 2011; Karali et al. 2013) or quantified risk as ignition probability maps, coupled with statistical analyses that explained observed ignition patterns with socioeconomic factors. These latter studies employed a wide range of statistical and methodological approaches such as logistic regression, Bayesian statistics, and neural networks (Vasilakos et al. 2007; Romero-Calcerrada et al. 2008; Catry et al. 2009; Martinez et al. 2009; Ager et al. 2014b).

An alternative body of literature has employed wildfire simulation modeling to better understand spatiotemporal patterns in wildfire risk and associated drivers. These studies include large-scale exposure assessments (Thompson et al. 2011; Ager et al. 2014a), evaluation of fuel treatment strategies (Ager et al. 2010a, b), endangered species habitat protection (Ager et al. 2007), landscape-level forest planning (González-Olabarria and Pukkala 2011), watersheds protection (Thompson et al. 2013b), incident-level decision support (Calkin et al. 2011b; Noonan-Wright et al. 2011), localized assessment of risk to structures or values (Ager et al. 2012; Haas et al. 2013; Salis et al. 2013, 2014;
Thompson et al. 2013a), and evaluation of climate change impacts (Arca et al. 2012). The use of wildfire simulations in fire exposure assessment at landscape scales allows the mapping of burn probability and associated fire intensities in relation to key drivers including weather, fuel, topography, and spatial ignition patterns (Miller and Ager 2013).

In this paper, we use wildfire simulation modeling to explore spatiotemporal patterns of wildfire exposure factors for Sardinia, Italy. The island is one of the regions most affected by wildfires in Italy and is a fire-prone area of particular interest also because it represents well the Mediterranean environments and conditions. In contrast to previous work in this area, we examined the combined effects of seasonal variation of weather, fuel moisture and types, topography, and historical fire occurrence on wildfire exposure. Specifically, we investigated how burn probability, fire size, and intensity change over the fire season and how the resulting seasonal pattern leads to specific trends in wildfire exposure to highly valued resources. We then discuss how the study can improve wildfire risk management on fire-prone Mediterranean landscapes.

\section{Methods}

Study area

The study area is Sardinia, Italy, the second largest island of the Mediterranean Basin (Fig. 1). The island has a topography characterized by the most relevant hills and mountains on the eastern side (Fig. 1) and plains located in the western part, with two main flat areas: Campidano in the South, and Nurra in the North. The highest peak is situated in central Sardinia and reaches about $1850 \mathrm{~m}$ a.s.l. (Fig. 1). The climate, albeit with some gradients from the coastal areas to the mountains, and from South to North, is characterized by a mild and rainy period, from October to May, and a warmer one, from June to September, with peaks above $30{ }^{\circ} \mathrm{C}$ in several days, and with a low incidence of rainfall (Table 1). The annual cumulative precipitation ranges from $500 \mathrm{~mm}$ in the coastal areas to about $1200 \mathrm{~mm}$ in the mountain peaks. Approximately half of Sardinia is covered by broadleaf forests (about $16 \%$ ), in particular Quercus spp., and Mediterranean shrubs 


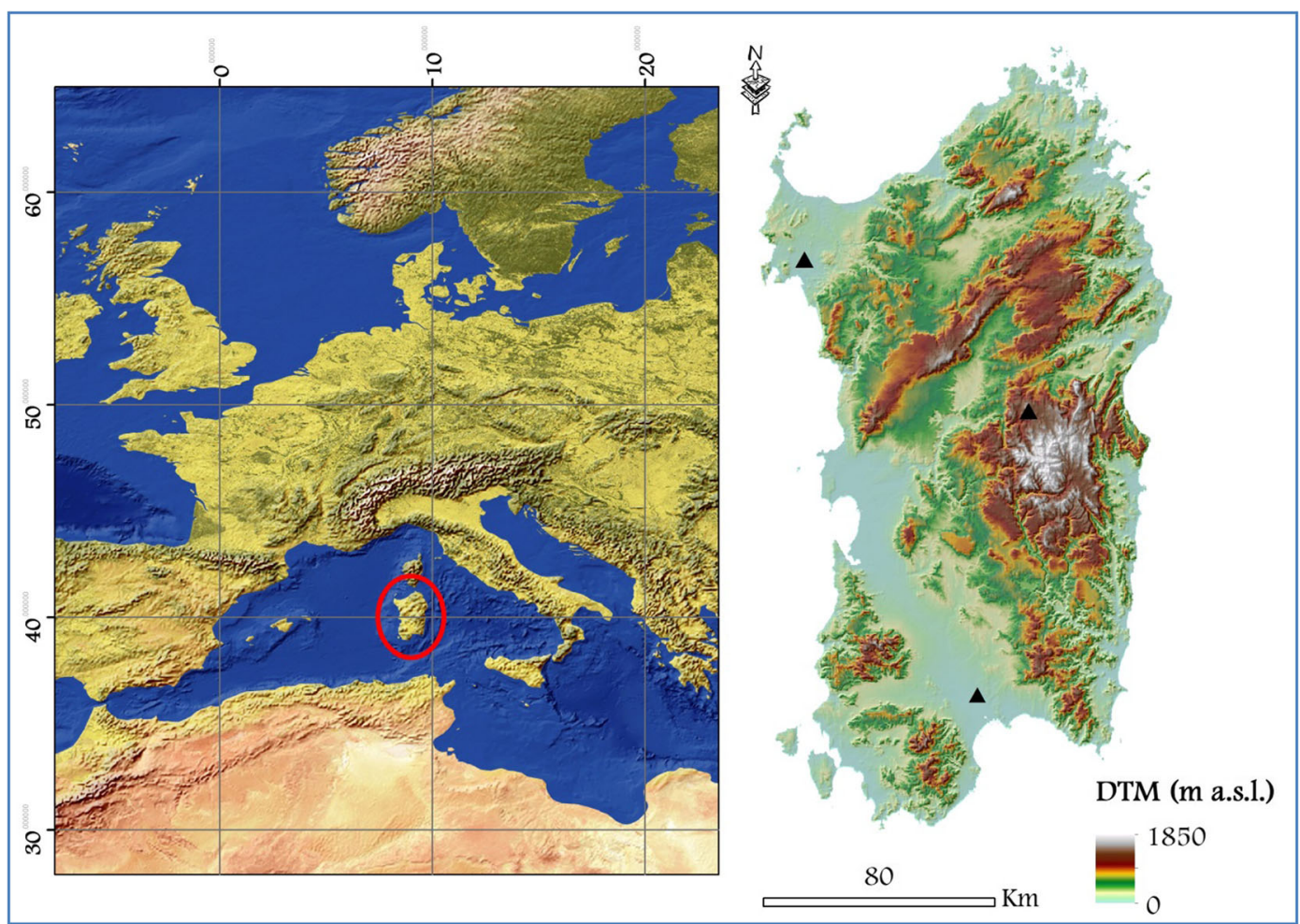

Fig. 1 Location of the island of Sardinia, Italy, in the Mediterranean basin. The figure on the right shows the elevation map (as derived by the 10-m DTM - digital elevation model — of Sardinia) of the island. The weather stations used in this study are represented by the black triangles

Input data for wildfire simulations

\section{Fire occurrence database}

We determined historical pattern of ignitions in Sardinia using a wildfire occurrence database that included observations from 1995 to 2009. This database consisted on information on ignition dates, municipality of
Table 1 Average values of mean temperature $\left(\mathrm{T},{ }^{\circ} \mathrm{C}\right)$ and cumulative precipitation (PP, $\mathrm{mm})$, as well as standard deviation, for the months of June, July, August, and September in Sardinia. The average values of maximum temperatures (TM) and minimum temperatures $(\mathrm{Tm})$ are provided for first, second, and third decades of the abovementioned months.

\begin{tabular}{lllllllll}
\hline Month & T & PP & TM1 & TM2 & TM3 & Tm1 & Tm2 & Tm3 \\
\hline Jun & $19.72 \pm 2.35$ & $22.03 \pm 8.29$ & 24.03 & 24.97 & 26.63 & 13.27 & 14.10 & 15.30 \\
Jul & $23.09 \pm 1.91$ & $7.23 \pm 4.52$ & 28.27 & 29.00 & 29.63 & 16.67 & 17.27 \\
Aug & $23.56 \pm 2.23$ & $16.90 \pm 7.20$ & 30.03 & 29.83 & 27.97 & 18.20 & 18.17 & 17.70 \\
Sep & $20.37 \pm 2.55$ & $42.60 \pm 6.86$ & 26.60 & 25.73 & 24.23 & 15.80 & 15.23 & 14.60 \\
\hline
\end{tabular}

The weather stations of Alghero (north), Decimomannu (south), and Fonni (center) were used as reference. The data were gathered from the Aeronautica Militare Italiana—Servizio Meteorologico (2009) 


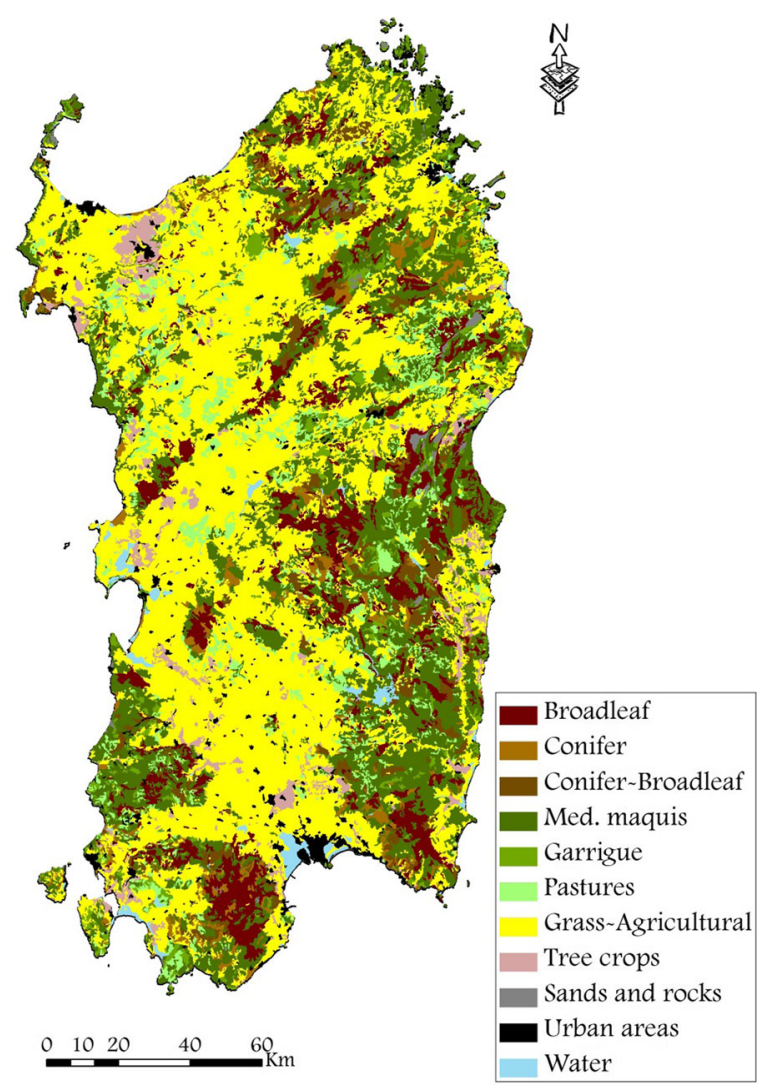

Fig. 2 Primary vegetation and land types in Sardinia as derived from the Sardinia Land Use Map of 2003 (www.sardegnageoportale.it)

ignition, coordinates, and final fire size. Within the study period (1995-2009), we analyzed all events occurred from June to September. In general, fires ignited after September and until June are relatively few in number and very small in size. We partitioned the data into eight time frames according to the ignition date as follows: 1 (1-15 June), 2 (16-30 June), 3 (1-15 July), 4 (16-31 July), 5 (1-15 August), 6 (16-31 August), 7 (115 September), and 8 (16-30 September) (Fig. 3). As shown in Fig. 4, Sardinia was affected by about 2,500 fires per year $\left(\sim 0.104\right.$ fires $\mathrm{km}^{-2}$ per year), with an average annual area burned of about 20,000 ha, and peaks activity observed in the time frame 4 (16-31 July). Relatively low activity was observed in early June and late September (Fig. 4).

\section{Topography and fuels}

Spatial data on topography (elevation, slope, aspect) and fuels (fuel models, canopy cover) were processed with
ArcFuels (Ager et al. 2011) as required by Randig (Finney 2002). The digital elevation model (10-m resolution, www.sardegnageoportale.it) was used to characterize elevation, slope, and aspect. Sardinia land use map of 2003 (shapefile, www.sardegnageoportale. it) was used as reference layer for the determination of the surface fuel models (Anderson 1982; Scott and Burgan 2005; Arca et al. 2009; Duce et al. 2012; Salis et al. 2013; Table 2). As presented in Table 2, we defined the following 12 fuel and land types: urban areas, water bodies, rocks and sands, grasslands, mixed agricultural areas, orchards and vineyards, herbaceous pastures, garrigue, Mediterranean maquis, broadleaf forests, conifer forests, and mixed forests. The canopy characteristics of the forest types were defined using the data reported by INFC (2005). Chemical and physical fuel properties were defined by associating to each fuel type either standard fuel models (NFFL (Anderson 1982) and FBM40 (Scott and Burgan 2005)) or custom fuel models specifically developed for Sardinia and Corsica vegetation (Duce et al. 2012; Salis et al. 2013) (Table 2). Both topography and fuels data were converted to ASCII files of 150-m resolution.

Live and dead fuel moistures for the eight time frames were set using a time series of fuel moisture data collected in northern Sardinia from 2003 to 2011 (Pellizzaro et al. 2007, 2009; personal communication). Live fuel moisture values for garrigue, Mediterranean maquis, Quercus spp. and Pinus spp. fuel types used in this work are shown in Fig. 5. The seasonal trend of fuel moisture used for the garrigue was determined combining the values measured during field surveys in Sardinia on Cistus monspeliensis L., Helichrysum italicum (Roth) G. Don, and Rosmarinus officinalis L.: These three species represent well the garrigue characteristics in Sardinia. The live moisture average pattern for Mediterranean maquis was determined considering the measurements performed in Arbutus unedo L., Pistacia lentiscus L., Phyllirea angustifolia L., and Juniperus phoenicea L. Furthermore, the trends of live fuel moisture of Pinus spp. and Quercus spp. were determined by combining a set of information and field surveys with data available in literature (Chuvieco et al. 2011). The live fuel moisture trend of mixed forests, which in the island are generally combinations of Quercus and Pinus spp. plantations, was considered equal to Quercus spp. 

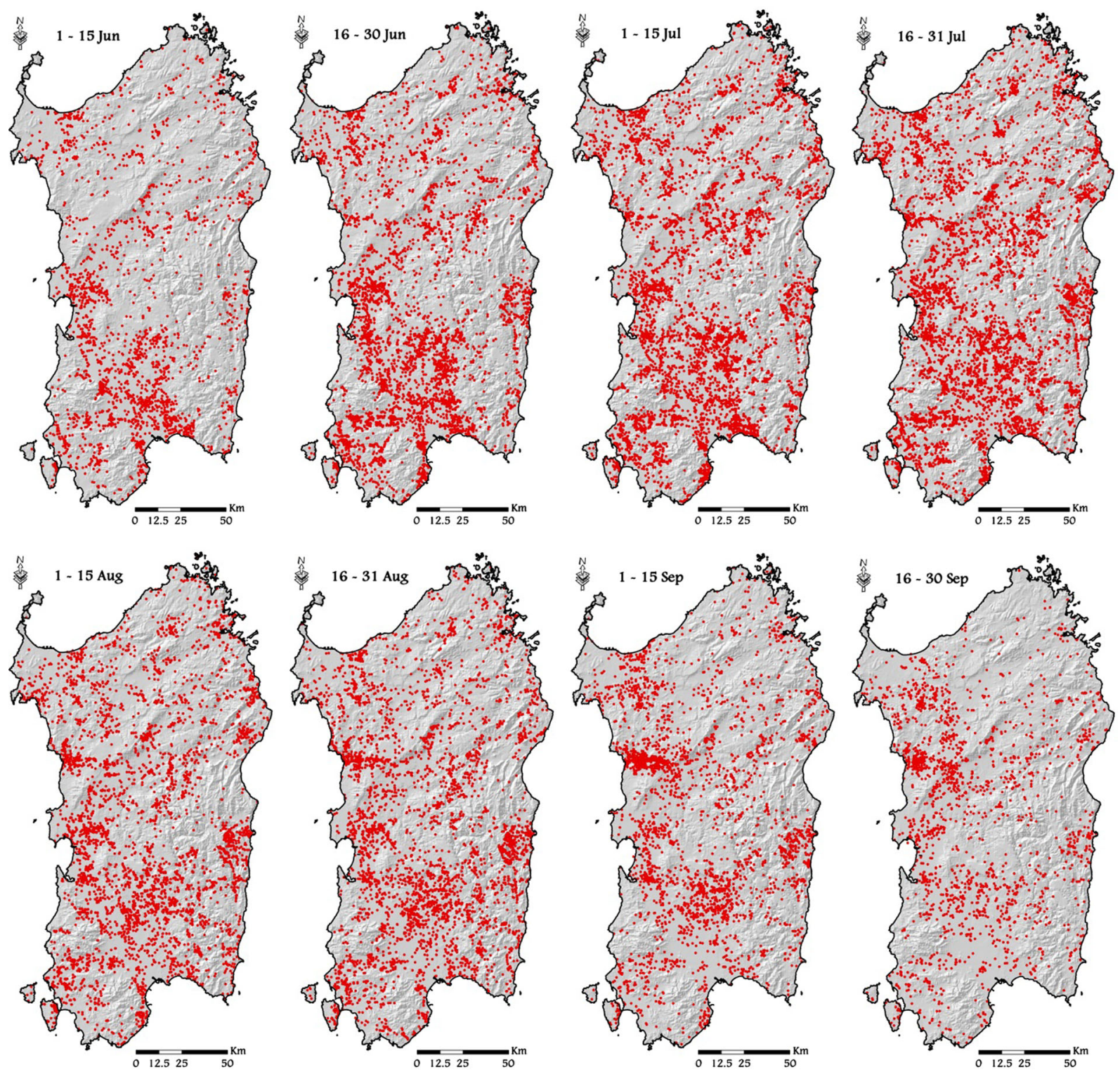

Fig. 3 Historical fire ignition points (red dots) in the island, from June to September, for the study period (1995-2009). Data from the Sardinia Forest Service (personal communication, 2010)

The dead fuel moisture values used in this work (Table 3) resulted from field sampling on litter, dead $1 \mathrm{~h}$, and 10-h fuels. Since dead fuel moisture is variable and strongly affected by weather conditions, specific probabilities of dead fuel moisture conditions were calculated within each time frame. This allowed for weighing the incidence of moderate, low, or extreme dead fuel moistures for each time frame. The data of dead fuel moisture reported in Table 3 were used for all surface fuels.

\section{Wind speed and direction}

A set of historical data on wind direction and speed observed in Sardinia during the summer season was gathered from Aeronautica Militare Italiana-Servizio Meteorologico (2009); the probability distribution of wind directions and intensities was calculated at monthly scale combining the wind data of three weather stations (Alghero, Decimomannu, and Fonni) located respectively in the north, south, and center of Sardinia. 


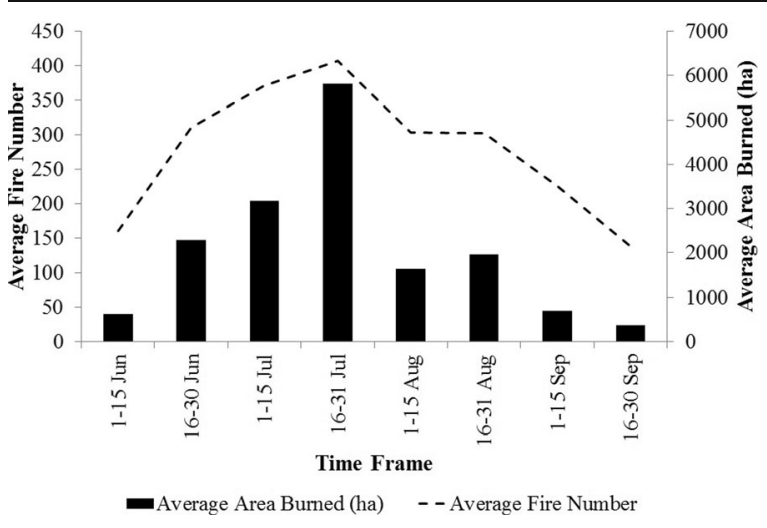

Fig. 4 Seasonal pattern of average fire number and area burned in Sardinia, from June to September, for the study period (19952009). Data from the Sardinia Forest Service (personal communication, 2010)

The data concerning wind speed and direction, together with the associated probability at monthly scale, are shown in Fig. 6.

\section{Highly valued resources data}

To analyze the spatial and temporal patterns of fire exposure for a set of features of interest during the eight time frames, we selected three highly valued resources (HVRs) of Sardinia: wildland urban interfaces (WUIs), vineyards and orchards (VAOs), and beaches and dunes (BCHs). These features are key values to be protected in case of wildfires, since VAOs are represented by highly valued agricultural areas, and in the surroundings of WUI and BCH human lives, goods and assets are directly threatened by flames and smoke. The HVR data were downloaded in shapefile format from the Sardinia Region website (www.sardegnageoportale.it). For each HVR, a buffer area of $500 \mathrm{~m}$ was identified in order to determine wildfire behavior and likelihood in the vicinity of the HVR. To identify the most critical situations in the surroundings of the selected HVR along the time frames, we set burn probability (BP) = 0.001 and conditional flame length $(\mathrm{CFL})=4.5 \mathrm{~m}$ as thresholds of reference. We selected $\mathrm{BP}=0.001$ as reference since it represents a simple indicator for fire management purposes and means that a given pixel will burn once for 1000 fire ignitions. As far as flame length is concerned, we selected the threshold based on the hauling charts of Andrews et al. 2011: flame lengths higher than $4.5 \mathrm{~m}$ are indicators of extreme fire behavior conditions (crowning, spotting, and major fire runs), where control efforts at the fire head are ineffective.

\section{Wildfire simulations}

Wildfire simulations were performed by using the minimum travel time (MTT) fire spread algorithm of Finney (2002) as implemented in a command line version of FlamMap called "Randig" (Finney 2006). The MTT algorithm replicates fire growth by Huygens' principle where the growth and behavior of the fire edge are a vector or wave front (Richards 1990; Finney 2002). The MTT fire spread model was previously calibrated in the study area as reported in several previous studies (i.e., Arca et al. 2012; Salis et al. 2012, 2013). We applied simulation modeling similar to that described in Salis et al.

Table 2 Vegetation types derived from the Sardinian Land Use Map of 2003 (www.sardegnageoportale.it), with the relative incidence in hectares and in percentage and the respective fuel models used for the wildfire simulations

\begin{tabular}{lccl}
\hline Vegetation type & Incidence $\left(10^{3}\right.$ ha) & Incidence $(\%)$ & Fuel model \\
\hline Broadleaf & 306.6 & 12.7 & TL3 (Scott and Burgan 2005) \\
Conifer & 66.5 & 2.8 & TL6 (Scott and Burgan 2005) \\
Broadleaf-conifer mix & 14.7 & 0.6 & TU1 (Scott and Burgan 2005) \\
Mediterranean maquis & 682.2 & 28.3 & CM28 (Arca et al. 2009) \\
Garrigue & 34.6 & 1.4 & CM29 (Arca et al. 2009) \\
Pastures & 162.4 & 6.8 & CM27 (Arca et al. 2009) \\
Grass-agricultural lands & 996.8 & 41.4 & Mod 1 (Anderson 1982) \\
Tree crops & 49.6 & 2.1 & Mod 2 (Anderson 1982) \\
Sands and rocks & 1.2 & 0.1 & Mod 1 (Anderson 1982, fuel load reduced of 50 \%) \\
Urban areas & 66.3 & 2.8 & NB1 (Scott and Burgan 2005) \\
Water bodies & 26.0 & 1.1 & NB8 (Scott and Burgan 2005) \\
\hline
\end{tabular}




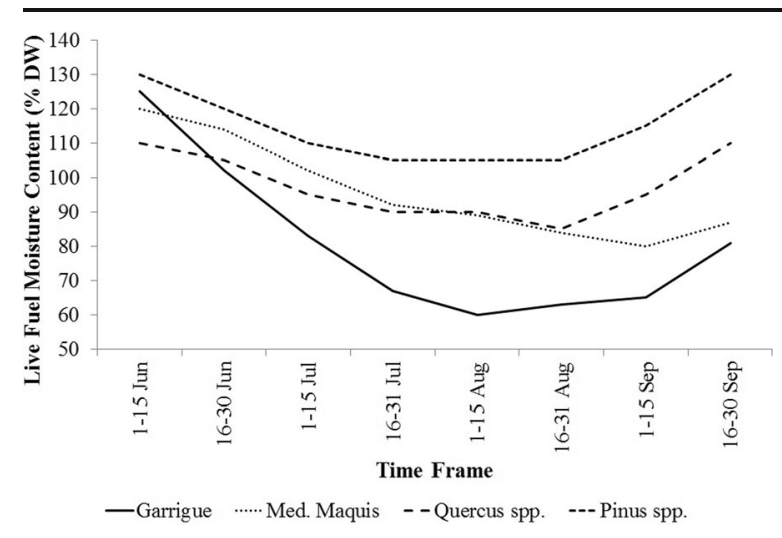

Fig. 5 Temporal patterns of average live fuel moisture for different fuel types in Sardinia, from June to September. These data were used as input for the wildfire simulations, as described in the "Methods"
$(2013,2014)$ to simulate a large number of wildfires and characterize spatial patterns in wildfire likelihood, intensity, and potential size in the island.

In this work, the simulations were stratified into eight time frames, according to the periods described above, and for each time frame, a specific set of fuel moistures and wind fields was used randomly sampling from the historical probabilities of occurrence. Regarding wind fields, the simulations were run using the wind fields produced by the mass-consistent model WindNinja (Forthofer 2007): Specifically, wind fields with definite directions and intensity were created from the historical weather scenarios (Aeronautica Militare ItalianaServizio Meteorologico (2009)) and then sampled in the simulations for each time frame. Concerning fuel

Table 3 Dead fuel moisture parameters used in the fire simulations for each time frame and for each time lag class

\begin{tabular}{|c|c|c|c|c|c|c|}
\hline \multirow[b]{2}{*}{ Time frame/time lag class } & \multicolumn{6}{|c|}{ Percentiles of dead fuel moisture values (\% DW) } \\
\hline & $97 t h$ & $90 t h$ & 75 th & 50 th & $25 t h$ & 3 th \\
\hline $1-15 \mathrm{Jun} / 1 \mathrm{~h}$ & 9 & 10 & 11 & 13 & 15 & 17 \\
\hline $1-15 \mathrm{Jun} / 10 \mathrm{~h}$ & 13 & 14 & 15 & 17 & 19 & 21 \\
\hline $1-15 \mathrm{Jun} / 100 \mathrm{~h}$ & 15 & 16 & 17 & 19 & 21 & 23 \\
\hline $16-30 \mathrm{Jun} / 1 \mathrm{~h}$ & 8 & 9 & 11 & 12 & 14 & 16 \\
\hline $16-30 \mathrm{Jun} / 10 \mathrm{~h}$ & 12 & 13 & 15 & 16 & 18 & 20 \\
\hline 16-30 Jun/100 h & 14 & 15 & 17 & 18 & 20 & 22 \\
\hline $1-15 \mathrm{Jul} / 1 \mathrm{~h}$ & 7 & 8 & 10 & 11 & 12 & 14 \\
\hline $1-15 \mathrm{Jul} / 10 \mathrm{~h}$ & 11 & 12 & 14 & 15 & 16 & 18 \\
\hline $1-15 \mathrm{Jul} / 100 \mathrm{~h}$ & 13 & 14 & 16 & 17 & 18 & 20 \\
\hline $16-31 \mathrm{Jul} / 1 \mathrm{~h}$ & 7 & 8 & 10 & 11 & 12 & 14 \\
\hline $16-31 \mathrm{Jul} / 10 \mathrm{~h}$ & 11 & 12 & 14 & 15 & 16 & 18 \\
\hline $16-31 \mathrm{Jul} / 100 \mathrm{~h}$ & 13 & 14 & 16 & 17 & 18 & 20 \\
\hline $1-15 \mathrm{Aug} / 1 \mathrm{~h}$ & 8 & 9 & 10 & 11 & 12 & 14 \\
\hline $1-15 \mathrm{Aug} / 10 \mathrm{~h}$ & 12 & 13 & 14 & 15 & 16 & 18 \\
\hline 1-15 Aug/100 h & 14 & 15 & 16 & 17 & 18 & 20 \\
\hline 16-31 Aug/1 h & 9 & 10 & 11 & 12 & 14 & 16 \\
\hline 16-31 Aug/10 h & 13 & 14 & 15 & 16 & 18 & 20 \\
\hline 16-31 Aug/100 h & 15 & 16 & 17 & 18 & 20 & 22 \\
\hline $1-15 \mathrm{Sep} / 1 \mathrm{~h}$ & 9 & 10 & 11 & 12 & 15 & 17 \\
\hline $1-15 \mathrm{Sep} / 10 \mathrm{~h}$ & 13 & 14 & 15 & 16 & 19 & 21 \\
\hline $1-15 \mathrm{Sep} / 100 \mathrm{~h}$ & 15 & 16 & 17 & 18 & 21 & 23 \\
\hline $16-30 \mathrm{Sep} / 1 \mathrm{~h}$ & 10 & 11 & 12 & 13 & 16 & 18 \\
\hline 16-30 Sep/10 h & 14 & 15 & 16 & 17 & 20 & 22 \\
\hline $16-30 \mathrm{Sep} / 100 \mathrm{~h}$ & 16 & 17 & 18 & 19 & 22 & 24 \\
\hline
\end{tabular}

The fuel moisture values were defined considering different percentiles and were calculated using data from several years of field sampling campaigns, as described in the "Methods" 


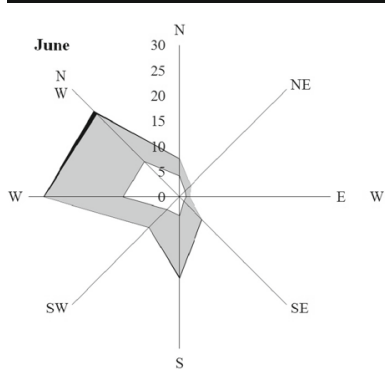

Fig. 6 Wind roses for June, July, August, and September in Sardinia. The axes report the frequency of each wind direction, in percentage. The weather stations of Alghero (north),

moistures, we used different scenarios with specific likelihood for the different time frames, as described in the previous paragraph and presented in Table 3. The fire ignition points were determined by sampling from a probability grid developed from the historical ignition database for each time frame of the study period (Fig. 3). The ignition probability grid was created with ArcGIS using the inverse distance weighting algorithm (ArcMap Spatial Analyst) and a search distance of $5000 \mathrm{~m}$.

For each time frame, we simulated 50,000 wildfires, sampling wind, weather, and ignitions from periodspecific distributions as described above. The fires were simulated for 10-h burn periods of propagation, which represent a common temporal window of active spread for the largest events that affected Sardinia in the last 20 years.

The simulations generated, for each time frame, burn probability maps, and flame length and fire size information for the whole island, at a resolution of $150 \mathrm{~m}$.

The BP represents the likelihood that a pixel will burn considering a single fire ignition in the entire study area and is defined as

$B P_{x y}=\left(\frac{F_{x y}}{N_{x y}}\right)$

where $F_{x y}$ is the number of times pixel XY burns and $N_{x y}$ is the number of simulated fires. Henceforth, BP is a relative measure and is useful for exposure analysis (Ager et al. 2011).

The wildfire intensity depends upon the direction from which the fire encounters a pixel relative to the major direction spread (i.e., heading, flanking, or backing fire), as well as upon slope and aspect (Finney 2002). To estimate fire intensity, Randig converts fireline intensity (FLI, in $\mathrm{kW} \mathrm{m}^{-1}$ ) to flame

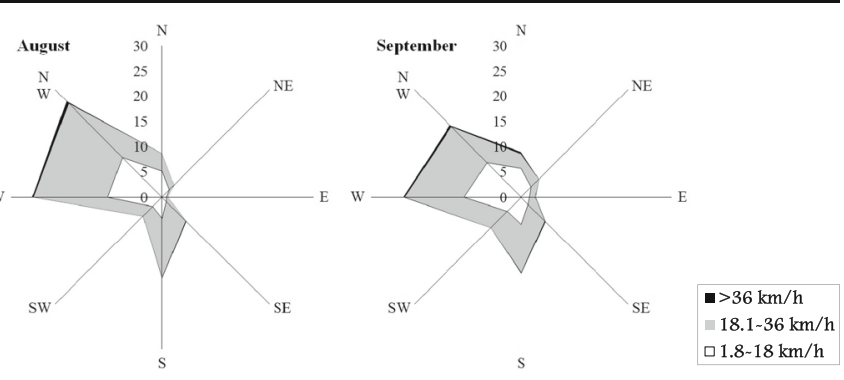

Decimomannu (south), and Fonni (center) were used as reference, as described in the "Methods." Data from Aeronautica Militare Italiana-Servizio Meteorologico (2009)

length (FL, in m) based on Byram's (1959) equation (Wilson 1980):

$F L=0.0775(F L I)^{0.46}$

Each pixel has a frequency distribution of flame length, which is divided into 20 classes of $0.5-\mathrm{m}$ interval; this distribution, generated from multiple fires burning a pixel, was used to calculate the CFL:

$\mathrm{CFL}=\sum_{i=1}^{20}\left(\frac{\mathrm{BP}_{\mathrm{i}}}{\mathrm{BP}}\right)\left(F_{i}\right)$

where $F L_{i}$ is the flame length midpoint of the $i$ th category. CFL is the probability-weighted flame length given a fire and is a measure of wildfire hazard (Scott 2006; Ager et al. 2011).

The fire size (FS) output from Randig is the XY ignition coordinate attributed with the area (ha) burned by the fire.

Finally, the temporal variations of BP, CFL, and FS were analyzed by the Kruskal-Wallis test, which is a nonparametric test used for comparing a set of independent samples to determine if the samples come from different populations. Being a nonparametric method, the Kruskal-Wallis test does not assume normal distribution of the residuals. The differences among time steps were tested considering $P=0.01$.

\section{Results}

Seasonal patterns of wildfire exposure profiles

The Kruskal-Wallis test revealed significant differences ( $P=0.01$, Table 4$)$ among the eight time frames considering all the variables analyzed (BP, CFL, and FS); the differences between time frames were also confirmed using fuel types as classification variable. The seasonal 
Table 4 Mean and standard deviation of BP, CFL (m), and FS (ha) for the different time frames, for the whole

Sardinia, considering the study period 1995-2009

BP, CFL, and FS mean values resulted significantly different for each time frame (Kruskal-Wallis test, $P<0.01$ ), as described in the text

\begin{tabular}{lllc}
\hline Time frame & BP & CFL & FS \\
\hline $1-15$ Jun & $1.50 \mathrm{E}-04 \pm 2.28 \mathrm{E}-04$ & $0.99 \pm 0.57$ & $652.1 \pm 663.4$ \\
$16-30$ Jun & $2.25 \mathrm{E}-04 \pm 2.53 \mathrm{E}-04$ & $1.20 \pm 0.66$ & $1056.0 \pm 890.7$ \\
$1-15$ Jul & $4.92 \mathrm{E}-04 \pm 4.68 \mathrm{E}-04$ & $1.43 \pm 0.85$ & $2351.5 \pm 1947.4$ \\
$16-31$ Jul & $6.72 \mathrm{E}-04 \pm 7.17 \mathrm{E}-04$ & $1.53 \pm 0.97$ & $3256.1 \pm 3155.8$ \\
$1-15$ Aug & $6.60 \mathrm{E}-04 \pm 8.04 \mathrm{E}-04$ & $1.47 \pm 1.00$ & $3190.3 \pm 3622.0$ \\
$16-31$ Aug & $4.72 \mathrm{E}-04 \pm 6.77 \mathrm{E}-04$ & $1.35 \pm 0.95$ & $2253.7 \pm 2861.5$ \\
$1-15$ Sep & $3.66 \mathrm{E}-04 \pm 5.31 \mathrm{E}-04$ & $1.37 \pm 0.99$ & $1727.3 \pm 2107.3$ \\
$16-30$ Sep & $2.71 \mathrm{E}-04 \pm 3.51 \mathrm{E}-04$ & $1.21 \pm 0.90$ & $1183.3 \pm 1202.8$ \\
\hline
\end{tabular}

pattern of the mean values of BP, CFL, and FS exhibited a peak in midsummer (time frame 4, 16-31 July), respectively of $6.72 \times 10^{-4}, 1.53 \mathrm{~m}$, and about 3250 ha (Table 4). The time frame 5 (1-15 August) showed similar but slightly lower values to those of time frame 4. The period with the lowest potential fire exposure was early June, when vegetation has relatively high live and dead moisture content (Table 3 and Fig. 5), thus retarding fire spread. The same conditions occur at the end of September, with strong reductions in BP, CFL, and FS with respect to the previous time frames. Fire intensity, as expressed by conditional flame length, showed similar values between time frames 6 (16-31 August) and 7 (1-15 September) (respectively 1.35 and $1.37 \mathrm{~m}$ ), in contrast to the patterns for BP and FS. Furthermore, BP, CFL, and FS exhibited a strong spatial variability along the season (Figs. 7, 8, and 9).

The wildfire likelihood was relatively low in time frame 1 (1-15 June), where only small spots in the southern part of the island were characterized by BP values higher than 0.002 (Fig. 7). In time frame 2, also other areas (i.e., southeast, specific areas of the eastern coast and central Sardinia) revealed high values of BP if compared to both the north area and the plains mainly covered by agriculture crops. From 1 to 15 August (time frame 5), the northeastern coastal area and a specific region of central-western Sardinia showed a net increase of BP compared to the previous periods (Fig. 7). After time frame 6 , thereafter, a progressive and marked reduction of wildfire likelihood was observed, with low $\mathrm{BP}$ values in time frame 8 . Yet, in early September, the central-west and south-central-east parts of the island, mainly covered by pastures and grasslands, continued to show relatively high values of $\mathrm{BP}$, due to the agropastoral practices that use fire to renew grazing areas and clean the field from vegetation residuals (Fig. 7).
Fire intensity presented a spatial pattern clearly linked to the fuel types and to the live and dead fuel moisture variations during the season, along with the terrain topography. The peak in fire intensity was observed in time frame 4 (Table 4, Fig. 8), even though from the beginning of July until the end of August, several areas also showed high values of CFL. On the whole, the eastern areas presented values of CFL higher than the rest of the island, probably because of the higher steepness and a greater presence of shrubland and Quercus fuel types, in comparison with the large amount of pastures and grasslands of the western sector. The maps showed strong spatial differences between late June and late September (Fig. 8), although the average CFL value was relatively similar (1.20 vs. $1.21 \mathrm{~m}$, Table 4): In time frame 2, in fact, the average CFL was generally low all over the island, while at the end of the fire season, CFL presented greater contrasts and a marked spatial variability (Fig. 8).

In terms of fire size (FS), the maps showed that some areas seemed to support large fire events (Fig. 9). The largest fire sizes were observed in late July. The areas with the most common occurrence of large fires were located in southeast Sardinia and in some spots of central Sardinia. By contrast, large fire events were relatively limited in northern Sardinia (Fig. 9) and at the beginning and the end of the wildfire season, when the largest simulated fires rarely affected more than 5000 ha (Table 4).

The shrubland fuel types (Mediterranean maquis and garrigue) resulted in relevant fire sources since the average BP of these fuel types was the highest among all fuels in several time frames, especially in midsummer (Table 5). The forest types showed a similar trend and evidenced BP values slightly lower than those of the garrigue during the most of time frames. The other fuel types showed much more limited BP, with the lowest values observed for grasslands in September and early June. Overall, Mediterranean maquis presented the 

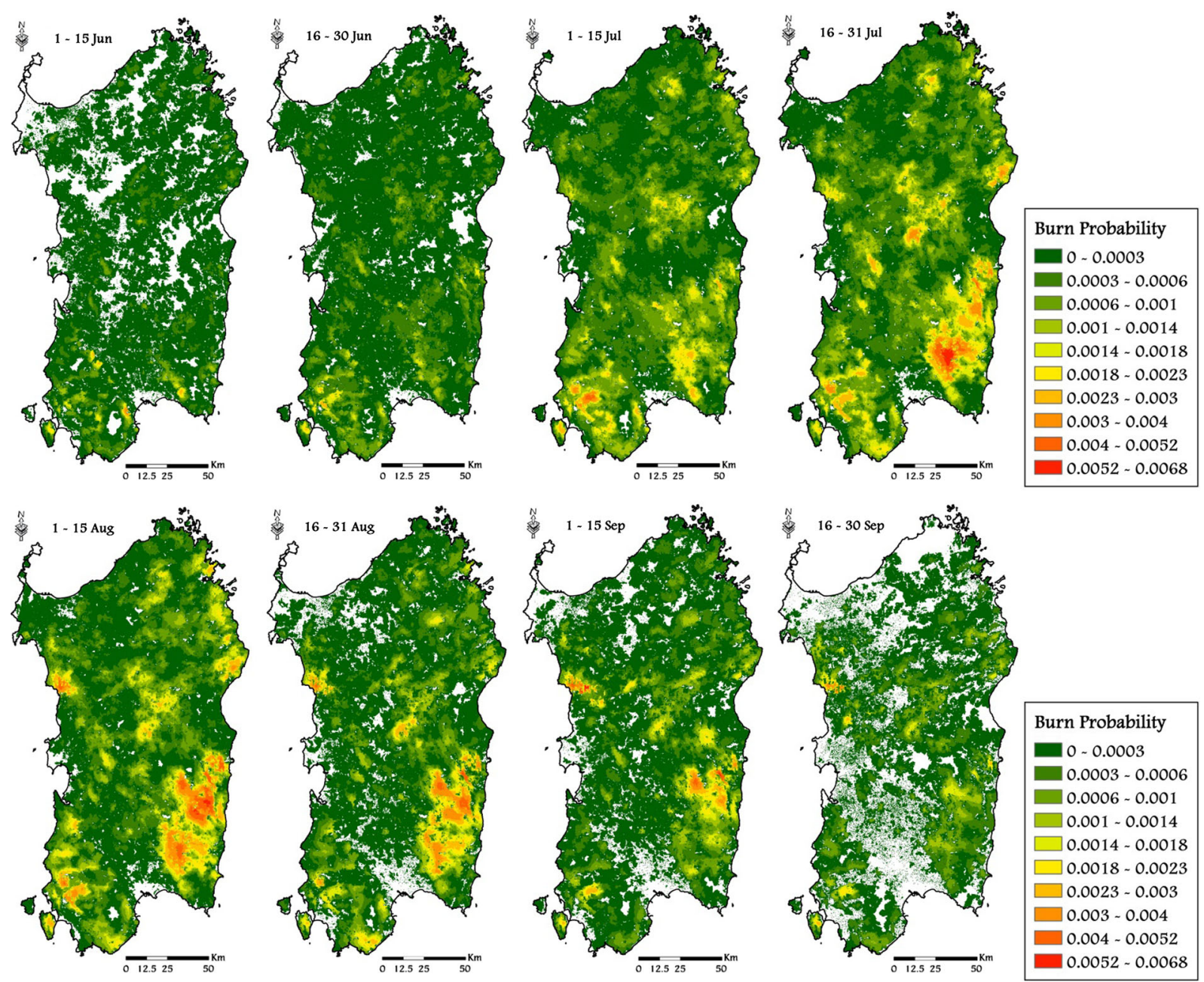

Fig. 7 Simulated spatiotemporal patterns of BP in Sardinia, from June to September, considering the historic conditions observed in the study period (1995-2009)

highest average CFL, with values above $2.5 \mathrm{~m}$ from early July until early September and peaks of about $3.1 \mathrm{~m}$ in time frames 4 and 5. The garrigue areas were also characterized by high fire intensity values, with average flame length close or above $1.5 \mathrm{~m}$ from early June until mid-September. By contrast, the lowest average CFL was observed in vineyards and orchards, as well as in mixed agricultural areas, both of which are mostly located in flat areas. Regarding forest fuel types, namely conifer and broadleaf stands, and mixed forest, the differences in both BP and CFL were limited, and in some time frames, the variation among conifer and mixed forests was not statistically significant. Generally, broadleaf presented higher values of fire intensity than the other forest types.
Seasonal patterns of wildfire exposure to HVRs

Seasonal patterns in exposure were similar for all HVRs, with beaches $(\mathrm{BCH})$ showing the lowest average BP values (Table 6). The peak of wildfire likelihood for beaches was observed in time frame 5 (1-15 August, $2.87 \times 10^{-4}$ ) and the lowest values at the beginning of June and at the end of September. A different pattern was observed when considering fire intensity, for which the beaches showed the highest values among the HVRs examined after July, with the peak in average CFL close to $1.35 \mathrm{~m}$ in time frame 4 . As far as the location of the areas most subject to very high wildfire likelihood and intensity is concerned, Fig. 10 shows that several beaches of northeast Sardinia presented values above 

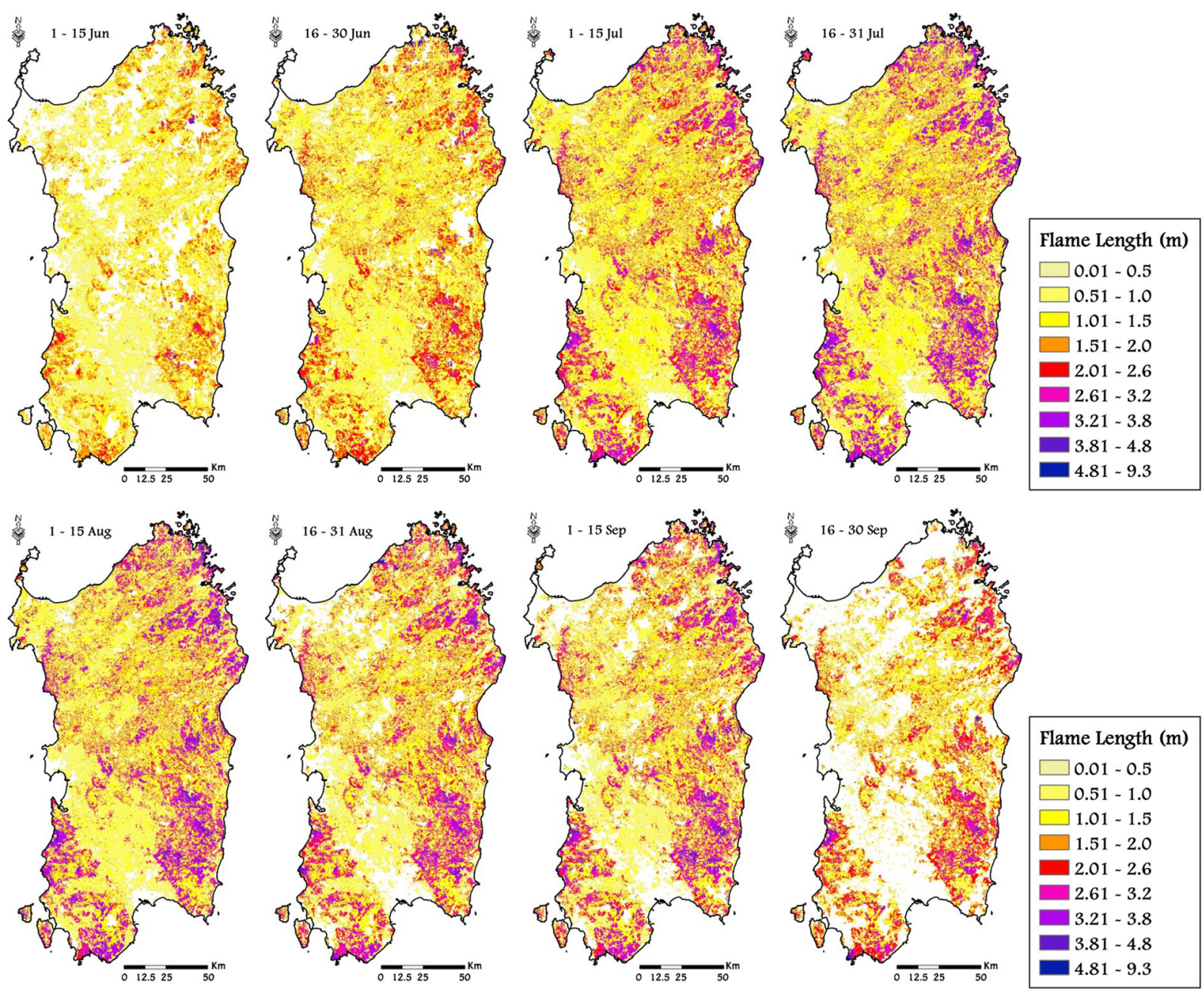

Fig. 8 Simulated spatiotemporal patterns of CFL in Sardinia, from June to September, considering the historic conditions observed in the study period (1995-2009)

our thresholds $(\mathrm{BP}>0.001$ and $\mathrm{CFL}>4.5 \mathrm{~m})$, in some cases even at the end of the season. Other areas with relatively high exposure were located in the eastern coast and in southwest Sardinia (Fig. 10).

Vineyards and orchards (VAOs) had mean BP values very similar to those observed in WUIs, although slightly lower in several cases, and with BP peaks observed in July (respectively $4.05 \times 10^{-4}$ and $4.39 \times 10^{-4}$ in time frames 3 and 4) (Table 6). In terms of CFL, the average fire intensity in VAOs was the lowest among the selected HVRs, with a peak in time frame $4(1.07 \mathrm{~m})$ and a minimum in time frame $8(0.40 \mathrm{~m})$. The areas with the highest values of CFL were mainly located in northern Sardinia, while on the other hand, the areas with the greatest wildfire likelihood were concentrated in specific areas of central Sardinia, in particular from early July to early September (Fig. 11).

Lastly, wildland urban interfaces (WUIs) showed the highest average BP values among the selected HVRs (Table 6). Maximum burn probabilities were observed for fires in the surrounding of WUIs between the beginning of July and early August, with the peak being registered in time frame $4\left(4.57 \times 10^{-4}\right)$. The average wildfire intensity in WUI areas was high compared to the other HVRs, especially early in the season (at the beginning and the end of June), and the average CFL from the beginning of July stood at slightly lower values than in BCHs. In time frame 4, the average flame length in WUIs reached a peak of $1.23 \mathrm{~m}$. Regarding the location of areas with the greatest wildfire likelihood 

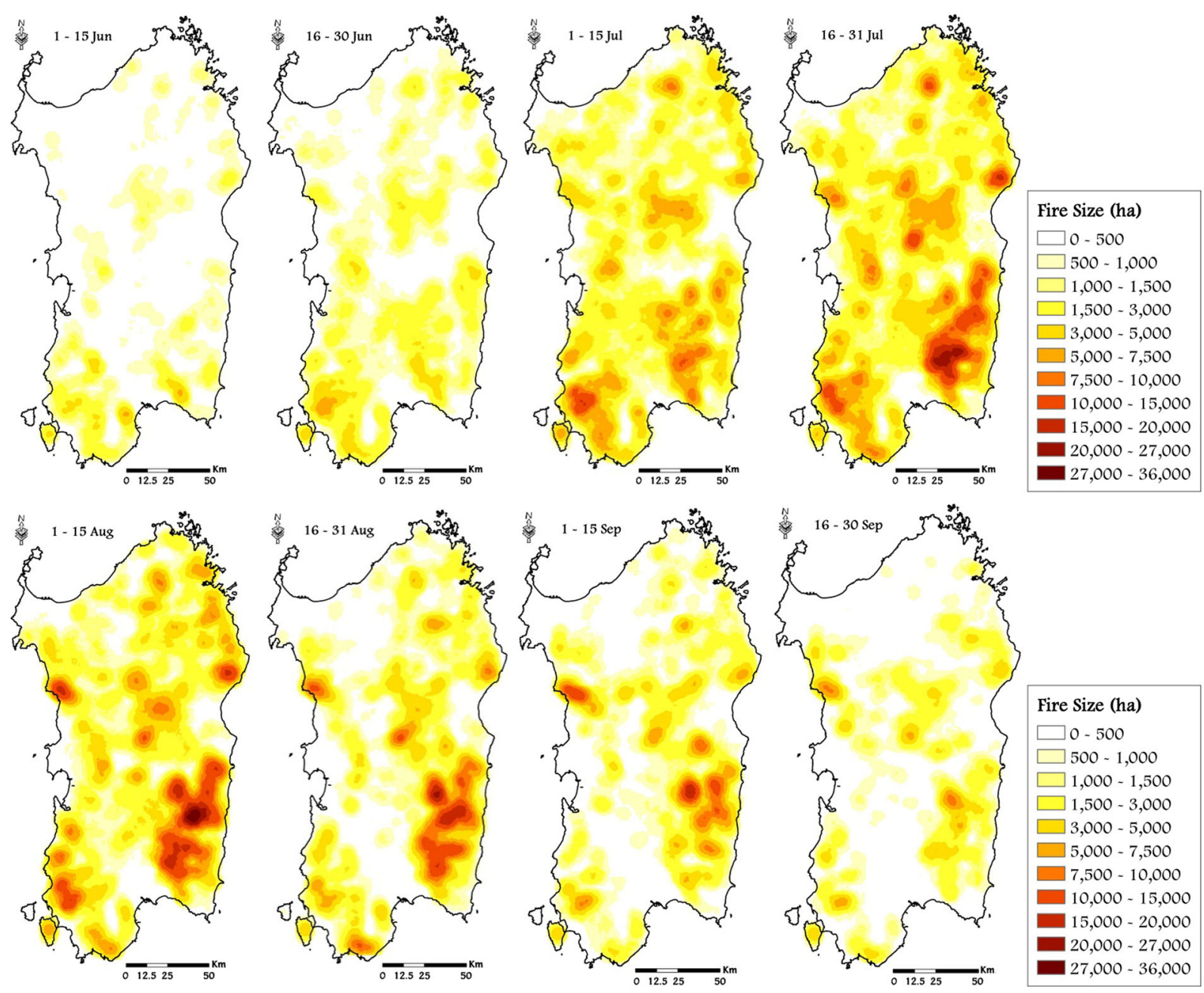

Fig. 9 Simulated spatiotemporal patterns of fire size in Sardinia, from June to September, considering the historic conditions observed in the study period (1995-2009)

and intensity, once again, the northeast coasts of the island were characterized by values above our stated thresholds, early at the end of June and until the end of September. This result indicates that, even from the beginning of the season, some WUIs may be subject to dangerous and severe fire events. In terms of BP, some very well-delimited WUI areas in the south of Sardinia and in the central-western part of the island showed high wildfire likelihood, particularly in July and August (Fig. 12).

\section{Discussion}

This study presented spatiotemporal patterns of wildfire exposure profiles based on spatially explicit burn probability and fire intensity as derived from landscape scale simulation modeling. In particular, this paper addressed the following questions: (1) How does potential wildfire likelihood, size, and intensity differ in the study area at different times during the fire season in Sardinia? (2) How do fuels contribute to the temporal variation in potential wildfire likelihood and intensity? (3) Are highly valued resources and assets characterized by different wildfire exposure profiles during the fire season?

The study area, Sardinia, Italy, is the second largest island of the Mediterranean Basin and had been affected by many severe wildfires over the past 50 years (Boni 2004; Salis et al. 2014). Although in recent years Sardinia experienced a sharp reduction in fire number and area burned, together with the enhancement and strengthening of aerial and terrestrial firefighting forces 
Table 5 Mean values of BP and CFL (m) for the different time frames, for diverse fuel types in Sardinia, considering the study period 1995-2009

\begin{tabular}{|c|c|c|c|}
\hline Time frame & Fuel type & $B P$ & $C F L$ \\
\hline \multirow[t]{9}{*}{ 1-15 Jun } & Grasslands & $6.45 \mathrm{E}-05$ & 0.657 \\
\hline & Mixed agricultural areas & $8.05 \mathrm{E}-05$ & 0.457 \\
\hline & Vineyards and orchards & 8.94E-05 & 0.368 \\
\hline & Herbaceous pastures & $1.17 \mathrm{E}-04$ & 0.556 \\
\hline & Garrigue & $1.70 \mathrm{E}-04$ & 0.903 \\
\hline & Mediterranean maquis & $2.41 \mathrm{E}-04$ & 1.713 \\
\hline & Conifer stands & $1.65 \mathrm{E}-04$ & 0.838 \\
\hline & Broadleaf stands & $1.63 \mathrm{E}-04$ & 1.029 \\
\hline & Mixed forests & $2.26 \mathrm{E}-04$ & 0.981 \\
\hline \multirow[t]{9}{*}{ 16-30 Jun } & Grasslands & $1.48 \mathrm{E}-04$ & 0.894 \\
\hline & Mixed agricultural areas & $1.52 \mathrm{E}-04$ & 0.653 \\
\hline & Vineyards and orchards & $1.55 \mathrm{E}-04$ & 0.551 \\
\hline & Herbaceous pastures & $1.95 \mathrm{E}-04$ & 0.821 \\
\hline & Garrigue & $2.66 \mathrm{E}-04$ & 1.258 \\
\hline & Mediterranean maquis & 3.29E-04 & 2.114 \\
\hline & Conifer stands & 2.39E-04 & 0.910 \\
\hline & Broadleaf stands & $2.31 \mathrm{E}-04$ & 1.111 \\
\hline & Mixed forests & $3.02 \mathrm{E}-04$ & 1.032 \\
\hline \multirow[t]{9}{*}{ 1-15 Jul } & Grasslands & $3.52 \mathrm{E}-04$ & 0.964 \\
\hline & Mixed agricultural areas & $3.73 \mathrm{E}-04$ & 0.701 \\
\hline & Vineyards and orchards & $3.72 \mathrm{E}-04$ & 0.611 \\
\hline & Herbaceous pastures & 4.71E-04 & 0.919 \\
\hline & Garrigue & $5.90 \mathrm{E}-04$ & 1.590 \\
\hline & Mediterranean maquis & $7.02 \mathrm{E}-04$ & 2.761 \\
\hline & Conifer stands & $4.90 \mathrm{E}-04$ & 0.988 \\
\hline & Broadleaf stands & 4.49E-04 & 1.215 \\
\hline & Mixed forests & 4.99E-04 & 1.119 \\
\hline \multirow[t]{9}{*}{$16-31 \mathrm{Jul}$} & Grasslands & $3.66 \mathrm{E}-04$ & 0.965 \\
\hline & Mixed agricultural areas & 4.34E-04 & 0.698 \\
\hline & Vineyards and orchards & $4.56 \mathrm{E}-04$ & 0.607 \\
\hline & Herbaceous pastures & $6.21 \mathrm{E}-04$ & 0.899 \\
\hline & Garrigue & $8.28 \mathrm{E}-04$ & 1.722 \\
\hline & Mediterranean maquis & $1.05 \mathrm{E}-03$ & 3.087 \\
\hline & Conifer stands & 7.47E-04 & 1.015 \\
\hline & Broadleaf stands & $6.63 \mathrm{E}-04$ & 1.257 \\
\hline & Mixed forests & $7.58 \mathrm{E}-04$ & 1.162 \\
\hline \multirow[t]{7}{*}{ 1-15 Aug } & Grasslands & $2.71 \mathrm{E}-04$ & 0.841 \\
\hline & Mixed agricultural areas & $3.74 \mathrm{E}-04$ & 0.625 \\
\hline & Vineyards and orchards & $4.16 \mathrm{E}-04$ & 0.527 \\
\hline & Herbaceous pastures & $5.90 \mathrm{E}-04$ & 0.775 \\
\hline & Garrigue & 8.39E-04 & 1.686 \\
\hline & Mediterranean maquis & $1.13 \mathrm{E}-03$ & 3.067 \\
\hline & Conifer stands & $7.54 \mathrm{E}-04$ & 1.000 \\
\hline
\end{tabular}

Table 5 (continued)

\begin{tabular}{|c|c|c|c|}
\hline Time frame & Fuel type & $B P$ & $C F L$ \\
\hline & Broadleaf stands & $6.55 \mathrm{E}-04$ & 1.247 \\
\hline & Mixed forests & $7.15 \mathrm{E}-04$ & 1.152 \\
\hline \multirow[t]{9}{*}{ 16-31 Aug } & Grasslands & 9.34E-05 & 0.690 \\
\hline & Mixed agricultural areas & $1.83 \mathrm{E}-04$ & 0.506 \\
\hline & Vineyards and Orchards & $2.36 \mathrm{E}-04$ & 0.421 \\
\hline & Herbaceous pastures & $3.53 \mathrm{E}-04$ & 0.590 \\
\hline & Garrigue & 5.89E-04 & 1.482 \\
\hline & Mediterranean maquis & $8.42 \mathrm{E}-04$ & 2.760 \\
\hline & Conifer stands & $5.80 \mathrm{E}-04$ & 0.951 \\
\hline & Broadleaf stands & $5.18 \mathrm{E}-04$ & 1.188 \\
\hline & Mixed forests & $6.68 \mathrm{E}-04$ & 1.113 \\
\hline \multirow[t]{9}{*}{ 1-15 Sep } & Grasslands & $9.61 \mathrm{E}-05$ & 0.678 \\
\hline & Mixed agricultural areas & $1.65 \mathrm{E}-04$ & 0.501 \\
\hline & Vineyards and Orchards & 2.05E-04 & 0.416 \\
\hline & Herbaceous pastures & $3.08 \mathrm{E}-04$ & 0.586 \\
\hline & Garrigue & 4.68E-04 & 1.439 \\
\hline & Mediterranean maquis & $6.07 \mathrm{E}-04$ & 2.823 \\
\hline & Conifer stands & $4.30 \mathrm{E}-04$ & 0.960 \\
\hline & Broadleaf stands & $4.00 \mathrm{E}-04$ & 1.187 \\
\hline & Mixed forests & 4.92E-04 & 1.115 \\
\hline \multirow[t]{9}{*}{ 16-30 Sep } & Grasslands & $5.22 \mathrm{E}-05$ & 0.324 \\
\hline & Mixed agricultural areas & $1.16 \mathrm{E}-04$ & 0.285 \\
\hline & Vineyards and Orchards & 1.49E-04 & 0.252 \\
\hline & Herbaceous pastures & $2.14 \mathrm{E}-04$ & 0.361 \\
\hline & Garrigue & 3.34E-04 & 1.138 \\
\hline & Mediterranean maquis & 4.10E-04 & 2.331 \\
\hline & Conifer stands & 2.89E-04 & 0.897 \\
\hline & Broadleaf stands & $2.62 \mathrm{E}-04$ & 1.104 \\
\hline & Mixed forests & $2.90 \mathrm{E}-04$ & 1.034 \\
\hline
\end{tabular}

as well as of their tactics, coordination, and organization, losses and fatalities from wildfires continue, and localized areas and periods of high wildfire risk persist on the island (Salis et al. 2013, 2014). The largest and most severe wildfires of the last years occurred on days with extreme weather and quickly escaped containment efforts of aerial and ground fire suppression resources (Cardil et al. 2013). For these reasons, there is a strong demand from fire agencies, policy makers, and communities to map wildfire risk at fine spatial and temporal scales and design appropriate fuel management and other prevention projects (Piñol et al. 2005, 2007; Calkin et al. 2011a). Wildfire simulation modeling can provide an important contribution to meet these needs when 
Table 6 Mean and standard deviation of BP and CFL (m) for the different time frames, for selected HVRs in Sardinia, for the study period (1995-2009)

\begin{tabular}{|c|c|c|c|c|c|c|}
\hline \multirow[t]{2}{*}{ Time frame } & \multicolumn{2}{|l|}{$\mathrm{BCH}$} & \multicolumn{2}{|l|}{ VAO } & \multicolumn{2}{|l|}{ WUI } \\
\hline & $B P$ & $C F L$ & $B P$ & $C F L$ & $B P$ & $C F L$ \\
\hline 1-15 Jun & $5.49 \mathrm{E}-05 \pm 7.65 \mathrm{E}-05$ & $0.583 \pm 0.508$ & $8.83 \mathrm{E}-05 \pm 1.09 \mathrm{E}-04$ & $0.551 \pm 0.272$ & $9.14 \mathrm{E}-05 \pm 1.39 \mathrm{E}-04$ & $0.600 \pm 0.360$ \\
\hline 16-30 Jun & $9.21 \mathrm{E}-05 \pm 1.32 \mathrm{E}-04$ & $0.840 \pm 0.606$ & $1.77 \mathrm{E}-04 \pm 1.60 \mathrm{E}-04$ & $0.852 \pm 0.251$ & $1.70 \mathrm{E}-04 \pm 1.87 \mathrm{E}-04$ & $0.932 \pm 0.387$ \\
\hline 1-15 Jul & $2.28 \mathrm{E}-04 \pm 2.16 \mathrm{E}-04$ & $1.204 \pm 0.654$ & $4.05 \mathrm{E}-04 \pm 3.15 \mathrm{E}-04$ & $1.032 \pm 0.303$ & $4.18 \mathrm{E}-04 \pm 3.65 \mathrm{E}-04$ & $1.170 \pm 0.447$ \\
\hline $16-31 \mathrm{Jul}$ & $2.85 \mathrm{E}-04 \pm 2.80 \mathrm{E}-04$ & $1.347 \pm 0.791$ & $4.39 \mathrm{E}-04 \pm 4.12 \mathrm{E}-04$ & $1.068 \pm 0334$ & $4.57 \mathrm{E}-04 \pm 4.23 \mathrm{E}-04$ & $1.230 \pm 0.509$ \\
\hline 1-15 Aug & $2.87 \mathrm{E}-04 \pm 3.61 \mathrm{E}-04$ & $1.208 \pm 0.755$ & $3.72 \mathrm{E}-04 \pm 5.11 \mathrm{E}-04$ & $0.952 \pm 0.356$ & $4.18 \mathrm{E}-04 \pm 4.70 \mathrm{E}-04$ & $1.127 \pm 0.527$ \\
\hline 16-31 Aug & $1.41 \mathrm{E}-04 \pm 2.03 \mathrm{E}-04$ & $1.079 \pm 0.805$ & $1.91 \mathrm{E}-04 \pm 3.71 \mathrm{E}-04$ & $0.731 \pm 0.413$ & $2.13 \mathrm{E}-04 \pm 3.19 \mathrm{E}-04$ & $0.891 \pm 0.553$ \\
\hline $1-15$ Sep & $1.12 \mathrm{E}-04 \pm 1.67 \mathrm{E}-04$ & $1.020 \pm 0.796$ & $1.68 \mathrm{E}-04 \pm 3.10 \mathrm{E}-04$ & $0.658 \pm 0.410$ & $1.54 \mathrm{E}-04 \pm 2.41 \mathrm{E}-04$ & $0.825 \pm 0.567$ \\
\hline 16-30 Sep & $5.79 \mathrm{E}-05 \pm 1.07 \mathrm{E}-04$ & $0.506 \pm 0.682$ & $8.68 \mathrm{E}-05 \pm 1.57 \mathrm{E}-04$ & $0.403 \pm 0.397$ & $8.31 \mathrm{E}-05 \pm 1.39 \mathrm{E}-04$ & $0.485 \pm 0.519$ \\
\hline
\end{tabular}

properly calibrated and validated to take into account local conditions (Arca et al. 2007; Duguy et al. 2007; Ager et al. 2011; Calkin et al. 2011a). In our case, the modeling approach provided relevant information in terms of landscape scale spatiotemporal patterns in
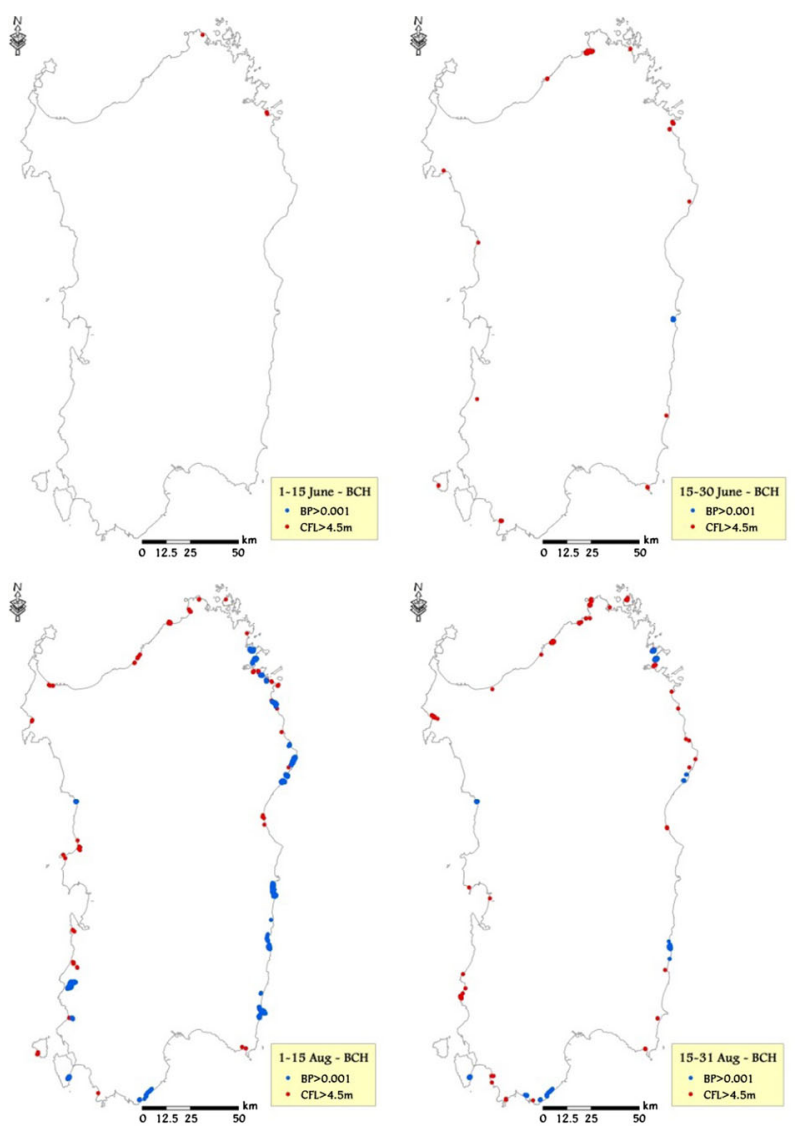
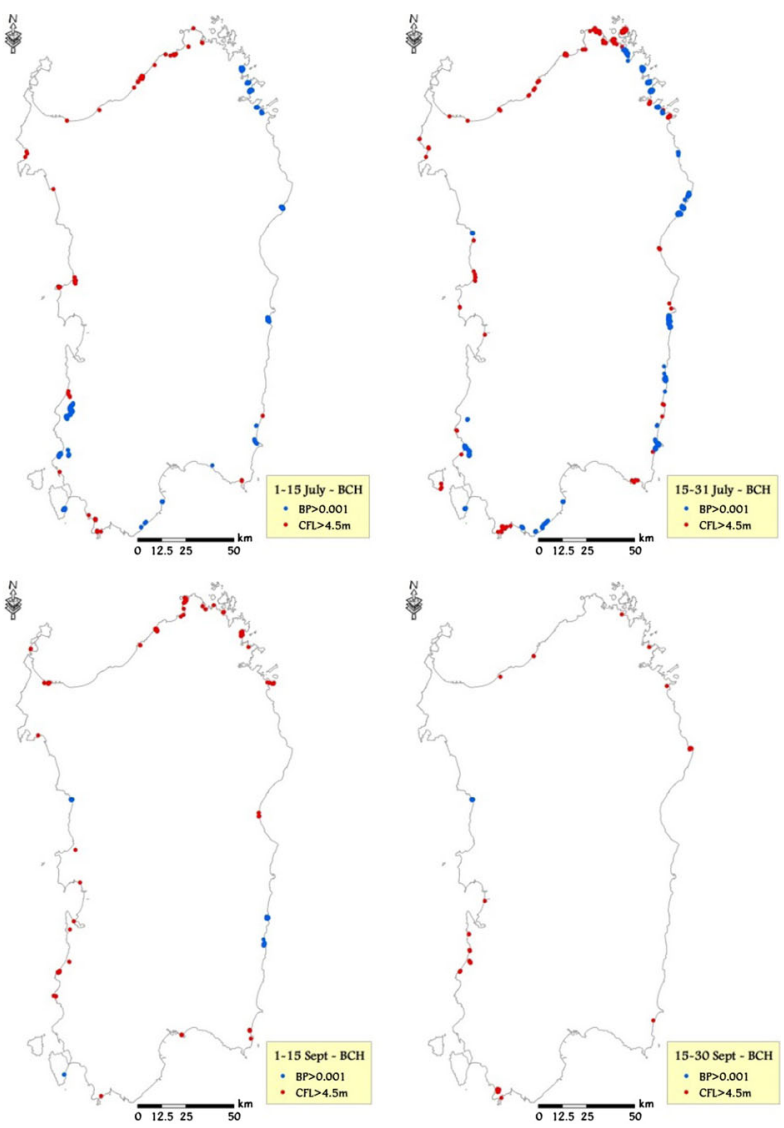

Fig. $10 \mathrm{BCH}$ areas characterized by the highest values of burn probability $(>0.001)$ and conditional flame length $(>4.5 \mathrm{~m})$ for the different time frames, considering the historic conditions observed in the study period (1995-2009) 


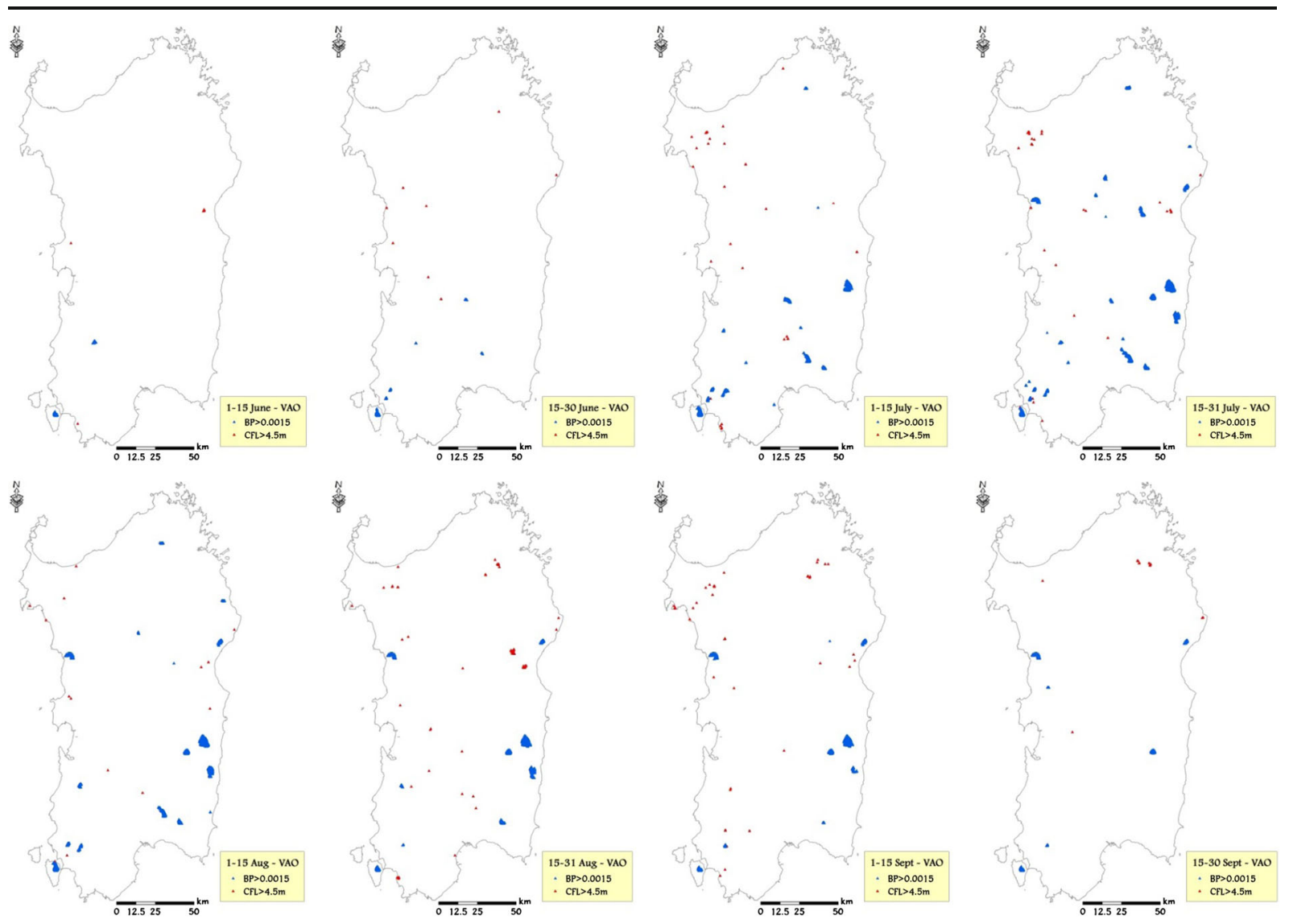

Fig. 11 VAO areas characterized by the highest values of burn probability $(>0.001)$ and conditional flame length $(>4.5 \mathrm{~m})$ for the different time frames, considering the historic conditions observed in the study period (1995-2009)

moisture, fire ignition locations, and winds. Overall, the outputs from the simulation modeling were consistent with historical fire frequency and current knowledge about fire ecology within the study area (Regione Sardegna 2014). Our work identified specific periods in which Sardinia is most susceptible to intense and large fire events (16-31 July and 1-15 August), where the average simulated burn probability of the island was the highest of the fire season, as well as average fire size and flame length. Before and after this period, the fire exposure was observed to be characterized by lower fire likelihood, intensity, and average fire size. The above results are in accordance with other studies conducted over Mediterranean areas (Ganteaume et al. 2012; Ganteaume and Jappiot 2013; Karali et al. 2013), as well as with the official wildfire reports for the island (Regione Sardegna 2014; http://www.sardegnaambiente.it).

We observed clear differences in the ignition spatial distribution of Sardinia, both from coastal toward inner areas, as well as from South to North, particularly early in the fire season, and this spatial pattern influenced the burn probability maps. The spatiotemporal differences in burn probability can be partly explained by the lower potential evaporation and higher local precipitation amounts toward the inner areas (Chessa and Delitala 1997). It is also evident that some BP hot spots at the end of the fire season, mostly located in western Sardinia, result from the agropastoralism practices, which rely on the use of fire to clean the herbaceous and wooded pastures from unwanted vegetation. These areas have shallow rocky soils that make it difficult to use other vegetation control methods such as mechanical cultivation or mowing.

Both weather conditions and phenological variability as exhibited in fuel moisture trends during the fire season, as well as the historical location of ignitions during the different time frames, played a key role in the observed variations in the simulated exposure profiles in the island and affected the differences between southern areas and the rest of Sardinia, particularly early 

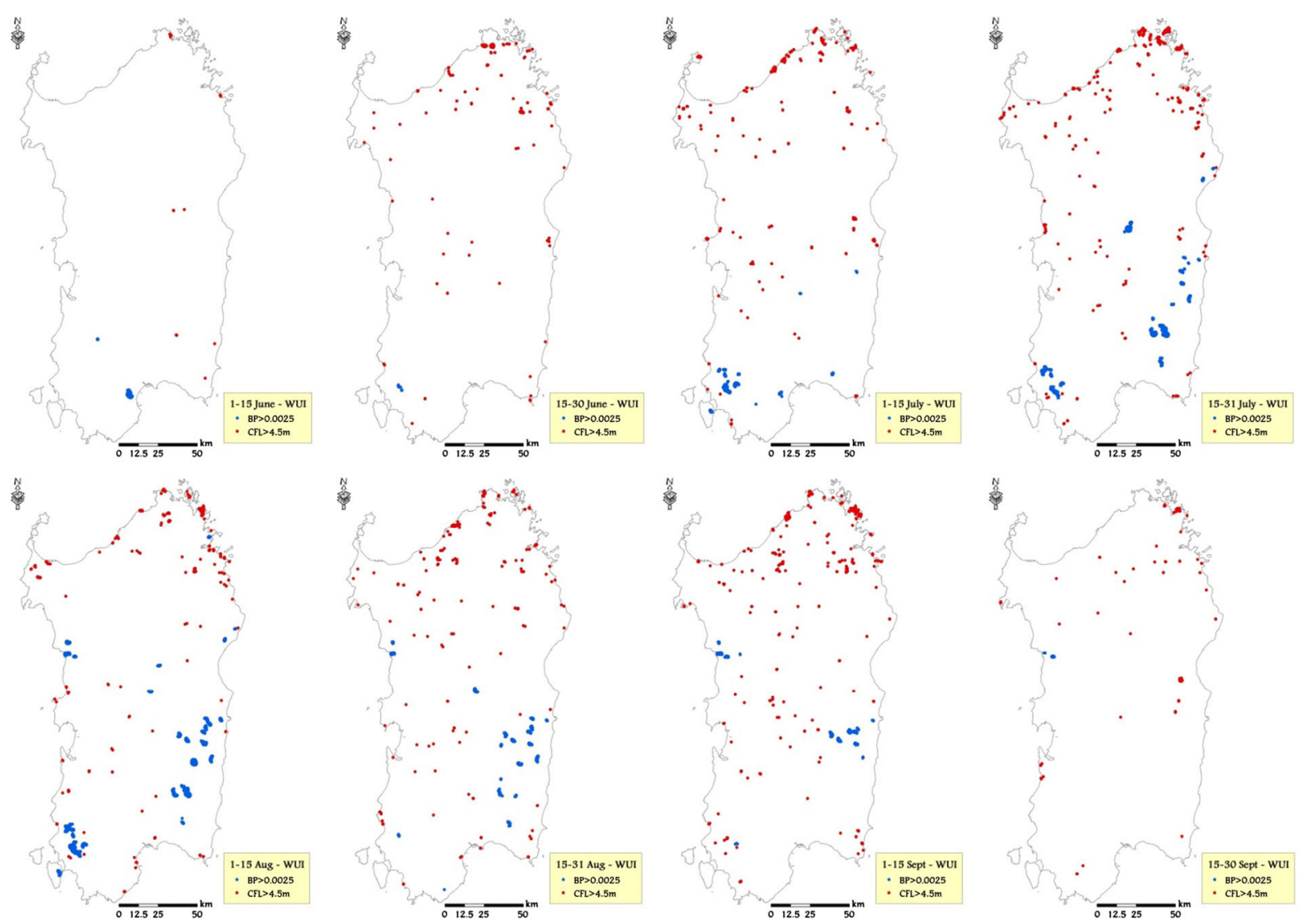

Fig. 12 WUI areas characterized by the highest values of burn probability $(>0.001)$ and conditional flame length $(>4.5 \mathrm{~m})$ for the different time frames, considering the historic conditions observed in the study period (1995-2009)

in the season. In terms of topographic effects on fire exposure, we observed the highest burn probability in hilly areas, and moreover, a relationship between modeled fire intensity and slope was evident. Furthermore, intense wildfires were more commonly observed in elevated hills and mountains, where high fuel loads and steep slopes are often combined. Another interesting point we investigated in this work was the influence of fuel models on fire exposure profiles. As expected, shrublands (Mediterranean garrigue and maquis) were characterized by high flame length, as well as high burn probability values, particularly in midsummer. By contrast, the agricultural and herbaceous areas presented on the whole low values of BP and CFL.

The wildfire exposure analysis performed for highly valued resources allowed for examination of exposure profiles of burn probability and fire intensity and illustrated differences in space and time. It is interesting to note that beaches had the highest BP in midsummer, from 16 July to 15 August, which is the period when the tourist pressure is the highest in Sardinia. Furthermore, the average flame length in the surroundings of $\mathrm{BCH}$ resulted higher than $1 \mathrm{~m}$ from the beginning of July until mid-September. These results suggest that prevention actions in the vicinity of beaches are needed to prevent damaging wildfires, since secure structures for protection are not commonly available in these areas, and natural vegetation is quite often unmanaged. Vineyards and orchards, generally located in managed areas, with low presence of woods and shrubs in the surroundings, presented the average lowest values of CFL, although some areas showed very high BP. The buffer areas of the wildland urban interfaces presented the highest values of BP among all values analyzed, with average BP higher than $4.0 \times 10^{-4}$ in July and early August. In the same period, fire intensity in these areas was on average the highest of the fire season.

On the whole, the maps of burn probability, fire size, and intensity allowed for quantitative representation of wildfire exposure at a scale that is not possible using 
other approaches such as analysis of historic ignition data, since these latter data do not contain information about fire intensity and do not account for fire spread in the landscape. Work is in progress to couple wildfire simulations with accurate nonparametric statistical models able to account for interactive effects of anthropogenic factors and weather variables on fire occurrence and size, calibrated for the study area, as well as to extend the methods to the whole Italy and other Mediterranean areas (Ager et al. 2014b).

The methodologies we used in this work can inform a spectrum of wildfire management activities, from realtime support during the fire season to fuel management and landscape planning, with the general goal of reducing fire exposure and losses from future wildfires. Moreover, the combination of geo-spatial data with landscape scale fire spread models allows for detailed assessments of the consequences of wildfires burning in different periods or areas (Miller and Ager 2013). Since all municipalities in Sardinia are asked to adopt plans of civil protection and emergency, this work can provide useful guidelines to policy makers and land managers to identify areas at risk and to select the most appropriate prevention and mitigation activities to protect ecosystems and specific values from wildfire losses. Furthermore, this study can help improving landscape scale awareness and understanding of spatial and temporal patterns of wildfire likelihood and intensity, thus allowing to inform different actions aimed to reduce landscape susceptibility and to contrast wildfire spread and ignitions, which in the study area are largely human caused and rarely natural. A detailed knowledge of the timing of wildfires in the different areas of the island can provide sound fundamentals for informing effective decision-support tool and managing fire risk and exposure under climate change scenarios and evolving landscapes. The approach used in this paper can also be used for a range of wildfire effects analyses, including smoke emissions, soil heating, duff consumption, soil erosion, and landslides.

Acknowledgments The authors would like to thank the Forest Service of Sardinia and the Sardinia Civil Protection for collaborating in this study. This work was partially funded by the GEMINA Project MIUR/MATTM n. 232/2011, by the EXTREME Project (Legge Regione Sardegna 7/2007, CRP-25405), and by the Project "Modeling approach to evaluate fire risk and mitigation planning actions" (P.O.R. SARDEGNA F.S.E. 20072013, Asse IV Capitale umano, Linea di Attività 1.3.1).

Open Access This article is distributed under the terms of the Creative Commons Attribution License which permits any use, distribution, and reproduction in any medium, provided the original author(s) and the source are credited.

\section{References}

Ager, A. A., Finney, M. A., Kerns, B. K., \& Maffei, H. (2007). Modeling wildfire risk to northern spotted owl (Strix occidentalis caurina) habitat in Central Oregon, USA. Forest Ecology and Management, 246, 45-56. doi:10.1016/ j.foreco.2007.03.070.

Ager, A. A., Finney, M. A., McMahan, A., \& Cathcart, J. (2010a). Measuring the effect of fuel treatments on forest carbon using landscape risk analysis. Natural Hazards and Earth System Sciences, 10, 2515-2526.

Ager, A. A., Vaillant, N. M., \& Finney, M. A. (2010b). A comparison of landscape fuel treatment strategies to mitigate wildland fire risk in the urban interface and preserve old forest structure. Forest Ecology and Management, 259(8), 1556-1570. doi:10.1016/j.foreco.2010.01.032.

Ager, A. A., Vaillant, N., \& Finney, M. A. (2011). Application of fire behavior models and geographic information systems for wildfire risk assessment and fuel management planning. Journal of Combustion. doi: $10.1155 / 2011 / 572452$.

Ager, A. A., Vaillant, N. M., Finney, M. A., \& Preisler, H. K. (2012). Analyzing wildfire exposure and source-sink relationships on a fire prone forest landscape. Forest Ecology and Management, 267, 271-283. doi:10.1016/j.foreco.2011.11. 021.

Ager, A. A., Day, M. A., McHugh, C. W., Short, K., GilbertsonDay, J., Finney, M. A., \& Calkin, D. E. (2014a). Wildfire exposure and fuel management on western US national forests. Journal of Environmental Management, 145, 54-70. doi:10.1016/j.jenvman.2014.05.035.

Ager, A. A., Preisler, H., Arca, B., Spano, D., \& Salis, M. (2014b). Wildfire risk estimation in the Mediterranean area. Environmetrics, 25(6), 384-396. doi:10.1002/env.2269.

Anderson HE (1982) Aids to determining fuel models for estimating fire behaviour. USDA Forest Service, Intermountain Forest and Range Experiment Station, General Technical Report INT-GTR-122, Ogden, UT.

Andrews PL, Heinschand FA, Schelvan L (2011) How to generate and interpret fire characteristics charts for surface and crown fire behavior. In: Gen. Tech. Rep. RMRS-GTR-253. Fort Collins, CO: U.S. Department of Agriculture, Forest Service, Rocky Mountain Research Station, 40p.

Arca, B., Duce, P., Laconi, M., Pellizzaro, G., Salis, M., \& Spano, D. (2007). Evaluation of FARSITE simulator in Mediterranean maquis. International Journal of Wildland Fire, 16, 563-572. doi:10.1071/WF06070.

Arca, B., Bacciu, V., Pellizzaro, G., Salis, M., Ventura, A., Duce, P., Spano, D., \& Brundu, G. (2009). Fuel model mapping by IKONOS imagery to support spatially explicit fire simulators. In E. Chuvieco \& R. Lasaponara (Eds.), 7th International Workshop on Advances in Remote Sensing in Forest Fire Management, 2-5 September 2009, Matera, Italy (pp. 75-78). Potenza, Italy: Il Segno, Arti Grafiche. 
Arca B, Pellizzaro G, Duce P, Salis M, Bacciu V, Spano D, Ager AA, Finney MA, Scoccimarro E (2012) Potential changes in fire probability and severity under climate change scenarios in Mediterranean areas. In Spano D, Bacciu V, Salis M, Sirca C (eds.), 2012. Modelling Fire Behaviour and Risk, pag. 9298. ISBN: 978-88-904409-7-7.

Arienti, M. C., Cumming, S. G., \& Boutin, S. (2006). Empirical models of forest fire initial attack success probabilities: the effects of fuels, anthropogenic linear features, fire weather, and management. Canadian Journal of Forest Research, 36, 3155-3166. doi:10.1139/x06-188.

Boni C (2004) Il Fenomeno degli Incendi in Sardegna. Proceedings of the Conference "Incendi Boschivi e Rurali in Sardegna - Dall'Analisi delle Cause alle Proposte di Intervento", 9-17. http://www.regione.sardegna.it/ documenti/1_39_20050927125327.pdf

Brotons, L., Aquilué, N. N., De Cáceres, M., Fortin, M. J., \& Fall, A. (2013). How fire history, fire suppression practices and climate change affect wildfire regimes in Mediterranean landscapes. PloS One, 8(5), e62392. doi:10.1371/journal.pone. 0062392.

Byram, G. M. (1959). Combustion of forest fuels. In 'Forest fire: control and use'. (Ed. KP Davis) pp. 61-89. McGraw-Hill: New York.

Calkin DE, Ager AA, Thompson MP (2011a) A comparative risk assessment framework for wildland fire management: the 2010 cohesive strategy science report. Gen. Tech. Rep. RMRS-GTR-262. Fort Collins, CO: U.S. Department of Agriculture, Forest Service, Rocky Mountain Research Station. 63 p.

Calkin, D. E., Thompson, M. P., Finney, M. A., \& Hyde, K. D. (2011b). A real-time risk assessment tool supporting wildland fire decision making. Journal of Forestry, 109(5), 274 280.

Cardil, A., \& Molina, D. M. (2013). Factors causing victims of wildland fires in Spain (1980-2010). Human and Ecological Risk Assessment: An International Journal. doi:10.1080/ 10807039.2013.871995.

Cardil, A., Molina, D. M., Ramirez, J., \& Vega-García, C. (2013). Trends in adverse weather patterns and large wildland fires in Aragón (NE Spain) from 1978 to 2010. Natural Hazards and Earth System Sciences, 13, 1393-1399. doi:10.5194/nhess13-1393-2013.

Cardil, A., Salis, M., Spano, D., Delogu, G., \& Molina Terrén, D. (2014). Large wildland fires and extreme temperatures in Sardinia (Italy). iForest, 7, 162-169.

Catry, F. X., Rego, F. C., Bação, F. L., \& Moreira, F. (2009). Modelling and mapping wildfire ignition risk in Portugal. International Journal of Wildland Fire, 18, 921-931.

Chessa, P. A., \& Delitala, A. (1997). Il clima della Sardegna. In A. Milella (Ed.), Collana Note tecniche di agrometeorologia per la Sardegna (pp. 17-38). Sassari: Chiarella.

Chuvieco E, Yebra M, Jurdao S, Aguado I, Salas FJ, García M, Nieto H, De Santis A, Cocero D, Riaño D, Martínez S, Zapico E, Recondo C, Martínez-Vega J, Martín MP, Riva J, Pérez F, Rodríguez-Silva F (2011) Field fuel moisture measurements on Spanish study sites. Department of Geography, University of Alcalá, Spain. Version 1. Available online at: http://www.geogra.uah.es/emilio/FMC_UAH.html

Curt, T., Borgniet, L., \& Bouillon, C. (2013). Wildfire frequency varies with the size and shape of fuel types in southeastern
France: implications for environmental management. Journal of Environmental Management, 117, 150-161. doi: 10.1016/j.jenvman.2012.12.006.

Duce P, Pellizzaro G, Arca B, Bacciu V, Salis M, Spano D, Santoni PA, Barboni T, Leroy V, Cancellieri D, Leoni E, Ferrat L, Perez Y (2012) Fuel types and potential fire behaviour in Sardinia and Corsica islands: a pilot study. In Spano D, Bacciu V, Salis M, Sirca C (eds.), 2012. Modelling Fire Behaviour and Risk, pag. 2-8. ISBN: 978-88-904409-7-7.

Duguy, B., Alloza, J. A., Röder, A., Vallejo, R., \& Pastor, F. (2007). Modelling the effects of landscape fuel treatments on fire growth and behaviour in a Mediterranean landscape (eastern Spain). International Journal of Wildland Fire, 16, 619-632.

Finney, M. A. (2002). Fire growth using minimum travel time methods. Canadian Journal of Forest Research, 32(8), 1420-1424. doi:10.1139/x02-068.

Finney MA (2006) An overview of FlamMap fire modeling capabilities. In 'Fuels management-how to measure success: conference proceedings', 28-30 March, Portland, OR. (Comp PL Andrews, BW Butler), USDA Forest Service, Rocky Mountain Research Station Proceedings RMRS-P41, pp. 213-220.

Forthofer JM (2007) Modeling wind in complex terrain for use in fire spread prediction. $\mathrm{PhD}$ thesis. Colorado State University.

Ganteaume, A., \& Jappiot, M. (2013). What causes large fires in Southern France. Forest Ecology and Management, 294, 7685. doi:10.1016/j.foreco.2012.06.055.

Ganteaume, A., Camia, A., Jappiot, M., San-Miguel-Ayanz, J., Long-Founel, M., \& Lampin, C. (2012). A review of the main driving factors of forest fire ignition over Europe. Environmental Management. doi:10.1007/s00267-0129961-z.

González-Olabarria, J. R., \& Pukkala, T. (2011). Integrating fire risk considerations in landscape-level forest planning. Forest Ecology and Management, 261, 278-287. doi:10.1016/j. foreco.2010.10.017.

González-Olabarria, J. R., Brotons, L., Gritten, D., Tudela, A., \& Teres, J. A. (2012). Identifying location and causality of fire ignition hotspots in a Mediterranean region. International Journal of Wildland Fire, 21(7), 905-914. doi:10.1071/ WF11039.

Haas, J. R., Calkin, D. E., \& Thompson, M. P. (2013). A national approach for integrating wildfire simulation modeling into Wildland Urban Interface risk assessments within the United States. Landscape and Urban Planning, 119, 44-53.

Hirsch, K. G., \& Martell, D. L. (1996). A review of initial attack fire crew productivity and effectiveness. International Journal of Wildland Fire, 6(4), 199-215. doi:10.1071/ WF9960199.

INFC (2005) Inventario Nazionale delle Foreste e dei Serbatoi Forestali di Carbonio. Ministero delle Politiche Agricole Alimentari e Forestali, Ispettorato Generale-Corpo Forestale dello Stato. CRA-Istituto Sperimentale per l'Assestamento Forestale e per l'Alpicoltura

Karali, A., Hatzaki, M., Giannakopoulos, C., Roussos, A., Xanthopoulos, G., \& Tenentes, V. (2013). Sensitivity and evaluation of current fire risk and future projections due to climate change: the case study of Greece. Natural Hazards Earth Systems Science Discussion, 1, 4777-4800. doi:10. 5194/nhessd-1-4777-2013. 
Lovreglio, R., Marciano, A., Patrone, A., \& Leone, V. (2012). Forest fire motives in Italy: preliminary results of a pilot survey in the most fire-affected Provinces. iForest, 9(4), 137-147. doi:10.3832/efor0693-009.

Martínez, J., Vega-Garcia, C., \& Chuvieco, E. (2009). Humancaused wildfire risk rating for prevention planning in Spain. Journal of Environmental Management, 90, 1241-1252. doi: 10.1016/j.jenvman.2008.07.005.

Miller, C., \& Ager, A. A. (2013). A review of recent advances in risk analysis for wildfire management. International Journal of Wildland Fire, 22, 1-14. doi:10.1071/WF11114.

Moreira, F., Viedma, O., Arianoutsou, M., Curt, T., Koutsias, N., Rigolot, E., Barbati, A., Corona, P., Vaz, P., Xanthopoulos, G., Mouillot, F., \& Bilgili, E. (2011). Landscape-wildfire interactions in southern Europe: implications for landscape management. Journal of Environmental Management, 92(10), 2389-2402.

Moreno, J. M., Vázquez, A., \& Vélez, R. (1998). Recent history of forest fires in Spain. In J. M. Moreno (Ed.), Large fires (pp. 159-185). Leiden, The Netherlands: Backhuys Publishers.

Mouillot, F., Ratte, J. P., Joffre, R., Moreno, J. M., \& Rambal, S. (2003). Some determinants of the spatio-temporal fire cycle in a Mediterranean landscape (Corsica, France). Landscape Ecology, 18, 665-674.

Noonan-Wright, E. K., Opperman, T. S., Finney, M. A., Zimmerman, G. T., Seli, R. C., Elenz, L. M., Calkin, D. E., \& Fiedler, J. R. (2011). Developing the US wildland fire decision support system (WFDSS). Journal of Combustion, 2011, 11-40. doi:10.1155/2011/168473.

Parisien, M. A., Snetsinger, S., Greenberg, J. A., Nelson, C. R., Schoennagel, T., Dobrowski, S. Z., \& Moritz, M. A. (2012). Spatial variability in wildfire probability across the western United States. International Journal of Wildland Fire, 21, 313-327. doi:10.1071/WF11044.

Pausas, J. G. (2004). Changes in fire and climate in the eastern Iberian Peninsula (Mediterranean basin). Climatic Change, 63, 337-350.

Pausas, J. G., \& Fernandez-Munoz, S. (2012). Fire regime changes in the Western Mediterranean Basin: from fuellimited to drought-driven fire regime. Climatic Change, $110,215-226$.

Pellizzaro, G., Duce, P., Ventura, A., \& Zara, P. (2007). Seasonal variations of live moisture content and ignitability in shrubs of the Mediterranean Basin. International Journal of Wildland Fire, 16, 633-641. doi:10.1071/WF05088.

Pellizzaro G, Ventura A, Arca B, Arca A, Duce P (2009) Weather seasonality and temporal pattern of live and dead fuel moisture content in Mediterranean shrubland. EGU General Assembly 2009, 19-24 April 2009, Vienna, Austria. http:// meetings.copernicus.org/egu2009, p.12100

Pereira, M. G., Trigo, R. M., DaCamara, C. C., Pereira, J. M. C., \& Leite, S. M. (2005). Synoptic patterns associated with large summer forest fires in Portugal. Agricultural and Forest Meteorology, 129, 11-25. doi:10.1016/J.AGRFORMET. 2004.12.007.

Piñol, J., Beven, K., \& Viegas, D. X. (2005). Modelling the effect of fire-exclusion and prescribed fire on wildfire size in Mediterranean ecosystems. Ecological Modelling, 183, 398-409. doi:10.1016/j.ecolmodel.2004.09.001.

Piñol, J., Castellnou, M., \& Beven, K. J. (2007). Conditioning uncertainty in ecological models: assessing the impact of fire management strategies. Ecological Modelling, 207, $34-44$. doi:10.1016/j.ecolmodel.2007.03.020.

Plucinski, M. P. (2013). Modeling the probability of Australian grassfires escaping initial attack to aid deployment decisions. International Journal of Wildland Fire, 22, 459-468. doi:10. 1071/WF12019.

Plucinski, M. P., McCarthy, G. J., Hollis, J. J., \& Gould, J. S. (2012). The effect of aerial suppression on the containment time of Australian wildfires estimated by fire management personnel. International Journal of Wildland Fire, 21, 219229. doi:10.1071/WF11063.

Pyne, S. J., Andrew, P. L., \& Laven, R. D. (1996). Introduction to wildland fire (2nd ed.). New York: John Wiley \& Sons, Inc.

Regione Sardegna (2014) Piano regionale di previsione, prevenzione e lotta attiva contro gli incendi boschivi 2014 2016. http://www.sardegnaambiente.it/index.php?xsl= $612 \& \mathrm{~s}=256124 \& \mathrm{v}=2 \& \mathrm{c}=4594 \&$ idsito $=20 \& \mathrm{~b}=1$

Richards, G. D. (1990). An elliptical growth model of forest fire fronts and its numerical solution. International Journal for Numerical Methods in Engineering, 30, 1163-1179.

Romero-Calcerrada, R., Novillo, C., Millington, J. D. A., \& Gomez-Jimenez, I. (2008). GIS analysis of spatial patterns of human-caused wildfire ignition risk in the SW of Madrid (Central Spain). Landscape Ecology, 23(3), 341-354. doi:10. 1007/s10980-008-9190-2.

Salis M, Arca B, Ager AA, Fois C, Bacciu V, Duce P, Spano D (2012) Extreme wildfire spread and behaviour: case studies from North Sardinia, Italy. Geophysical Research Abstracts, Vol. 14, 10052 p. ISSN 1607-7962

Salis, M., Ager, A. A., Arca, B., Finney, M. A., Bacciu, V., Duce, P., \& Spano, D. (2013). Assessing exposure of human and ecological values to wildfire in Sardinia, Italy. International Journal of Wildland Fire, 22(4), 549-565. doi:10.1071/ WF11060.

Salis, M., Ager, A. A., Finney, M. A., Arca, B., \& Spano, D. (2014). Analyzing spatiotemporal changes in wildfire regime and exposure across a Mediterranean fire-prone area. Natural Hazards, 71(3), 1389-1418. doi:10.1007/s11069-013-0951-0.

San-Miguel-Ayanz, J., Moreno, J. M., \& Camia, A. (2013). Analysis of large fires in European Mediterranean landscapes: lessons learned and perspectives. Forest Ecology and Management, 294, 11-22.

Scott JH (2006) An analytical framework for quantifying wildland fire risk and fuel treatment benefit. In "Fuels managementhow to measure success: conference proceedings; March 2830, Portland, OR” (Comps. Andrews, P.L., Butler, B.W) U.S. Department of Agriculture, Forest Service, Rocky Mountain Research Station, Proceedings RMRS-P-41, pp. 169-184. (Fort Collins, CO)

Scott, J. H., \& Burgan, R. (2005). Standard fire behavior fuel models: a comprehensive set for use with Rothermel's Surface Fire Spread Model, USDA Forest Service, Rocky Mountain Research Station, General Technical Report RMRS-GTR-153. CO: Fort Collins.

Aeronautica Militare Italiana - Servizio Meteorologico (2009) Atlante Climatico d'Italia. http://clima.meteoam.it/ AtlanteClimatico/Index.htm

Skinner, C. N., Abott, C., Fry, D. L., Stephens, S. L., Taylor, A. H., \& Trouet, V. (2009). Human and climatic influences on fire regimes in California's North Coast Range. Fire Ecology, 5(3), 76-99. doi:10.4996/fireecology.0503076. 
Thompson, M. P., Calkin, D. E., Gilbertson-Day, J. W., \& Ager, A. A. (2011). Advancing effects analysis for integrated, largescale wildfire risk assessment. Environmental Monitoring and Assessment, 179(1-4), 217-239. doi:10.1007/s10661010-1731-x.

Thompson, M. P., Scott, J., Kaiden, J. D., \& Gilbertson-Day, J. W. (2013a). A polygon-based modeling approach to assess exposure of resources and assets to wildfire. Natural Hazards, 67(2), 627-644. doi:10.1007/s11069-013-0593-2.

Thompson, M. P., Scott, J., Langowski, P. G., Gilbertson-Day, J. W., Haas, J. R., \& Bowne, E. M. (2013b). Assessing watershed-wildfire risks on national forest system lands in the rocky mountain region of the United States. Water, 5(3), 945-971. doi:10.3390/w5030945.

Vasilakos, C., Kalabokidis, K., Hatzopoulos, J., Kallos, G., \& Matsinos, J. (2007). Integrating new methods and tools in fire danger rating. International Journal of Wildland Fire, 16, 306-316.
Verde, J. C., \& Zezere, J. L. (2010). Assessment and validation of wildfire susceptibility and hazard in Portugal. Natural Hazards and Earth System Sciences, 10, 485-497.

Viegas, D. X., Simeoni, A., Xanthopoulos, G., Rossa, C., Ribeiro, L. M., Pita, L. P., Stipanicev, D., Zinoviev, A., Weber, R., Dold, J., Caballero, D., \& San Miguel, J. (2009). Recent forest fire related accidents in Europe (pp. 1018-5593). Luxembourg: Office for Official Publications of the European Communities. ISSN. doi:10.2788/50781. ISBN 978-92-79-14604-6.

Wilson, R. (1980). Reformulation of forest fire spread equations in SI units. USDA Forest Service, Intermountain Forest \& Range Experiment Station, Research Note INT-292. UT: Odgen.

Xystrakis, F., Kallimanis, A. S., Dimopoulos, P., Halley, J. M., \& Koutsias, N. (2013). Precipitation dominates fire occurrence in Greece (1900-2010). Natural Hazards and Earth System Science, 1, 693-720. doi:10.5194/nhessd-1-693-2013. 